\title{
Reducing effort in the U.S. American lobster (Homarus americanus) fishery to prevent North Atlantic right whale (Eubalaena glacialis) entanglements may support higher profits and long-term sustainability
}

\author{
Hannah J. Myers ${ }^{1,2,3}$ and Michael J. Moore ${ }^{1}$ \\ ${ }^{1}$ Biology Department, Woods Hole Oceanographic Institution, Woods Hole, MA 02543 U.S.A. \\ ${ }^{2}$ International Fund for Animal Welfare, Yarmouth Port, MA 02674 U.S.A. \\ ${ }^{3}$ College of Fisheries and Ocean Sciences, University of Alaska Fairbanks, Fairbanks, AK 99775 \\ U.S.A.
}

\begin{abstract}
North Atlantic right whales (Eubalaena glacialis) feed and migrate in areas of the inshore and offshore trap fishery for American lobster (Homarus americanus) in the Northeast U.S. In addition to a recent increase in lethal and sub-lethal interactions with Canadian snow crab gear, entanglement in both Canadian and U.S. lobster trap gear threatens the continued existence of this endangered species. The U.S. National Marine Fisheries Service is considering a number of measures to prevent right whale entanglement bycatch that could impact lobster fishing effort. The U.S. lobster fishery in Maine expends approximately 7.5 times as much effort as the Canadian fishery in Lobster Fishing Area 34, where fishers catch about 3.7 times more lobster per trap than Maine fishers. From 2007 to 2013 in Maine, lobster landings doubled as the number of traps fell 10.5 percent and landings per trap increased by about 125 percent. The state of Massachusetts has achieved record high landings since trap/pot seasonal closures have been implemented to protect right whales, especially within the Statistical Reporting Areas most affected by the closures. Therefore, a negative economic impact should not be assumed with effort reduction. In fact, reducing effort may serve to increase fishing profits while supporting the protection of endangered North Atlantic right whales and the long-term sustainability of the lobster fishery.
\end{abstract}

Keywords: bycatch, fisheries management, North Atlantic right whales, overfishing, fishing technology, ropeless fishing

\section{Background}

The United States' National Marine Fisheries Service (NMFS) is preparing significant new regulations designed to reduce bycatch of endangered North Atlantic right whales (Eubalaena glacialis) in the American lobster (Homarus americanus) fishery. Entanglement in fixed fishing gear, which, in U.S. waters, is dominated by gear from the American lobster fishery, is the leading cause of mortality among North Atlantic right whales (Pettis et al. 2018; Sharp et al. 2019) and has important sublethal impacts on the species' ability to recover (van der Hoop et al. 2017). Many of the measures NMFS is considering could lead to a reduction in fishing effort. Myers et al. (2007) showed how reducing effort would benefit both the U.S. lobster industry and the North Atlantic right whale. Here we extend that concept by exploring how overcapacity and effort reduction are connected to American lobster landings and revenue in the U.S. fishery.

\section{A. The U.S. American lobster fishery}


The American lobster fishery is the United States' most valuable fishery, bringing in over US $\$ 670$ million in landings revenue in 2016 (NMFS Annual Commercial Landings Statistics). It is based in the Northeast, especially the states of Maine, Massachusetts, New Hampshire, and Rhode Island, and is fished using fixed trap/pot fishing gear. Trap/pot fishing gear consists of a baited trap or string of traps (referred to as a trawl) on the seafloor connected to a surface buoy with a vertical buoyline or "endline." The surface buoy and endline serve to mark the location of the trap or trawl for the owner and other fixed and mobile fishing gear (i.e. scallop dredge and bottom trawl) operators operating in the area, as well as to allow the traps to be hauled up through the water column. The rope connecting traps in a trawl is referred to as "groundline." Since 2007, NMFS has required fishers in most areas to use sinking or neutrally buoyant groundline due to the potential for floating groundline to entangle North Atlantic right whales (NMFS 2007).

However, North Atlantic right whales and other protected species-including humpback, fin, sei, and minke whales and loggerhead and leatherback sea turtles - are known to become entangled in trap/pot endlines (Hayes et al. 2018b; NMFS 2014) [Figure 1]. The U.S. American lobster fishery employs an estimated 912,300 vertical endlines during peak fishing months - many of which are within the North Atlantic right whale's designated Critical Habitat Area (NMFS 2016; NMFS co-occurrence model 2019) [Figures 2, 3]. The rope used for endlines has become significantly stronger over recent decades as manufacturing techniques have evolved, likely contributing to an increase in right whale entanglement severity and mortality as whales are less able to break free of entangling line and gear (Knowlton et al. 2016).

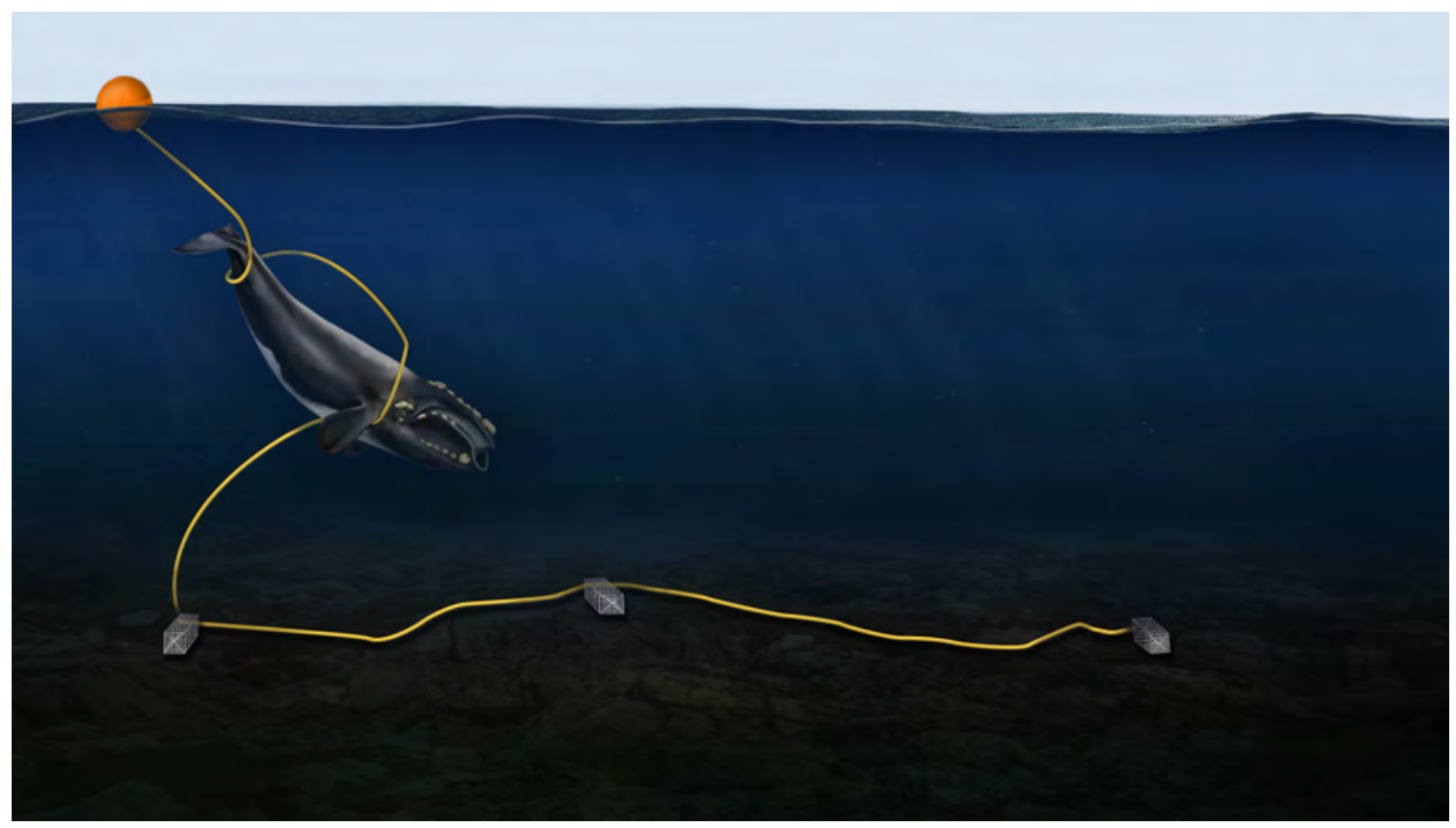

Figure 1: Illustration of a North Atlantic right whale entangled in vertical endline, showing the surface buoy, endline, and string of traps or "trawl" connected by sinking groundline. Credit: Natalie Renier, Woods Hole Oceanographic Institution 

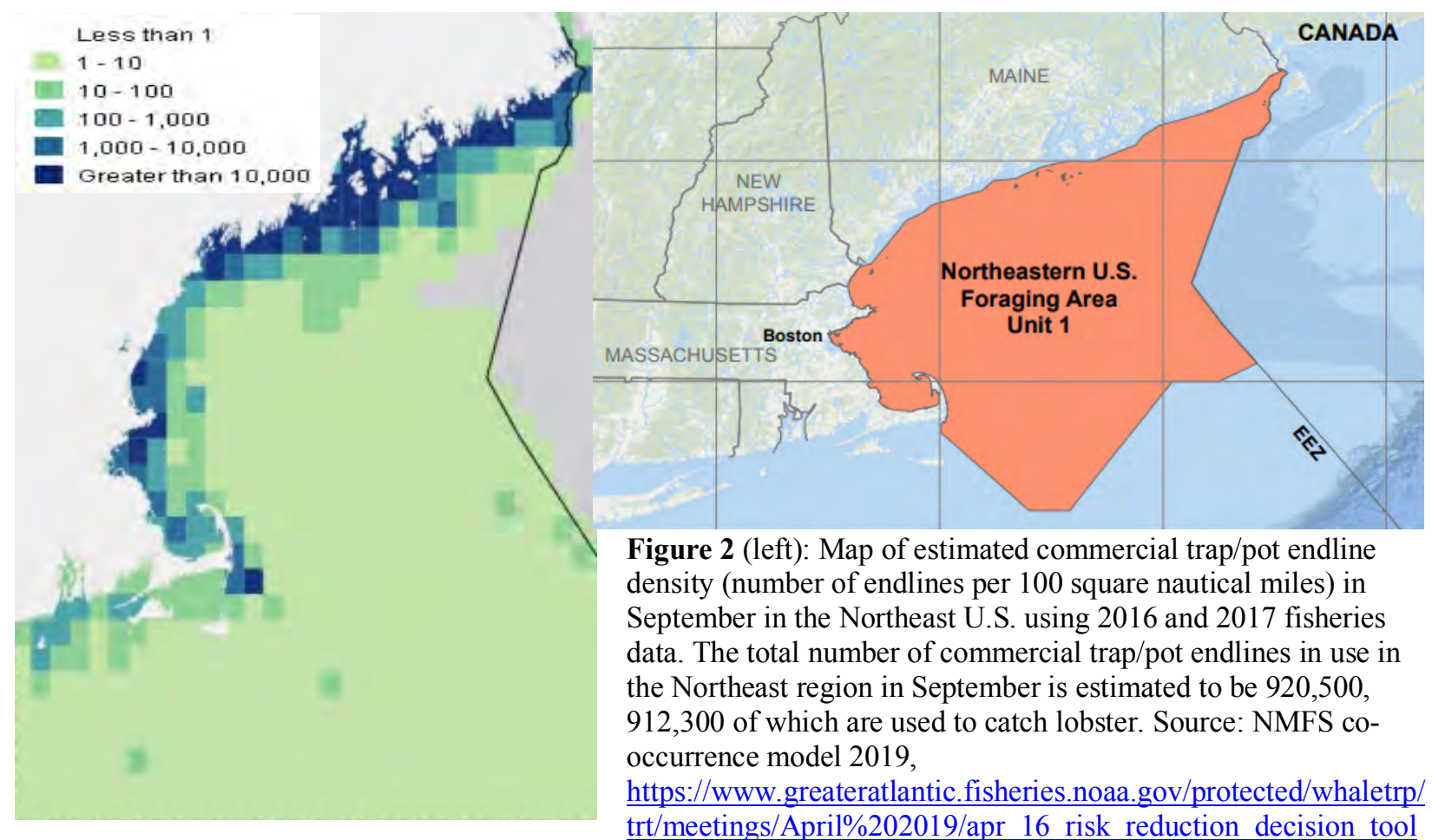

Figure 2 (left): Map of estimated commercial trap/pot endline density (number of endlines per 100 square nautical miles) in September in the Northeast U.S. using 2016 and 2017 fisheries data. The total number of commercial trap/pot endlines in use in the Northeast region in September is estimated to be 920,500, 912,300 of which are used to catch lobster. Source: NMFS cooccurrence model 2019,

https://www.greateratlantic.fisheries.noaa.gov/protected/whaletrp/ trt/meetings/April\%202019/apr_16 risk reduction_decision tool

webinar_full slide deck.pdf

Figure 3 (right): Map of North Atlantic right whale designated critical habitat area in the Northeast U.S. Source: NMFS 2016, available at https://www.fisheries.noaa.gov/resource/map/north-atlantic-right-whale-critical-habitatmap-and-gis-data.

The Atlantic States Marine Fisheries Commission (ASMFC) has divided the U.S. lobster stock into three biological areas: the Gulf of Maine, Georges Bank, and southern New England. According to the most recent stock assessment from 2015, the Gulf of Maine and Georges Bank stocks are not depleted and overfishing is not occurring, but the southern New England stock is severely depleted (ASMFC 2015). Climate change and associated disease and poor recruitment may be at least partly responsible for the collapse of the southern New England stock (ASMFC 2015). The Gulf of Maine stock accounts for more than 90 percent of U.S. landings (ASMFC 2015). The Gulf of Maine and Georges Banks stocks are heavily fished, especially in the fall, but stock abundance is also high (ASMFC 2015). However, in the most recent stock assessment from 2015, three of the five young of year indicators - which help indicate future sustainability of the stock-were low, which may suggest potential declines in recruitment in future years (ASMFC 2015). Using an annual larval settlement index and local bottom temperature and disease prevalence indicators, Oppenheim et al. (2019) predict that Gulf of Maine lobster landings will decline to near-historical levels within the next decade as the lobster population continues to recede poleward in a warming ocean.

The U.S. American lobster fishery has experienced robust growth in recent decades, with peak landings in 2016 of over 72,000 metric tons (nearly 160 million pounds) valued at more than $\$ 670$ million (NMFS Annual Commercial Landings Statistics). Landings value has also shown consistent growth. Total U.S. American lobster landings weight increased by 2.78 times from 1992 to 2016, while landings value increased by 2.24 times when adjusted for inflation (4.03 times nominal value) [Figure 4]. 


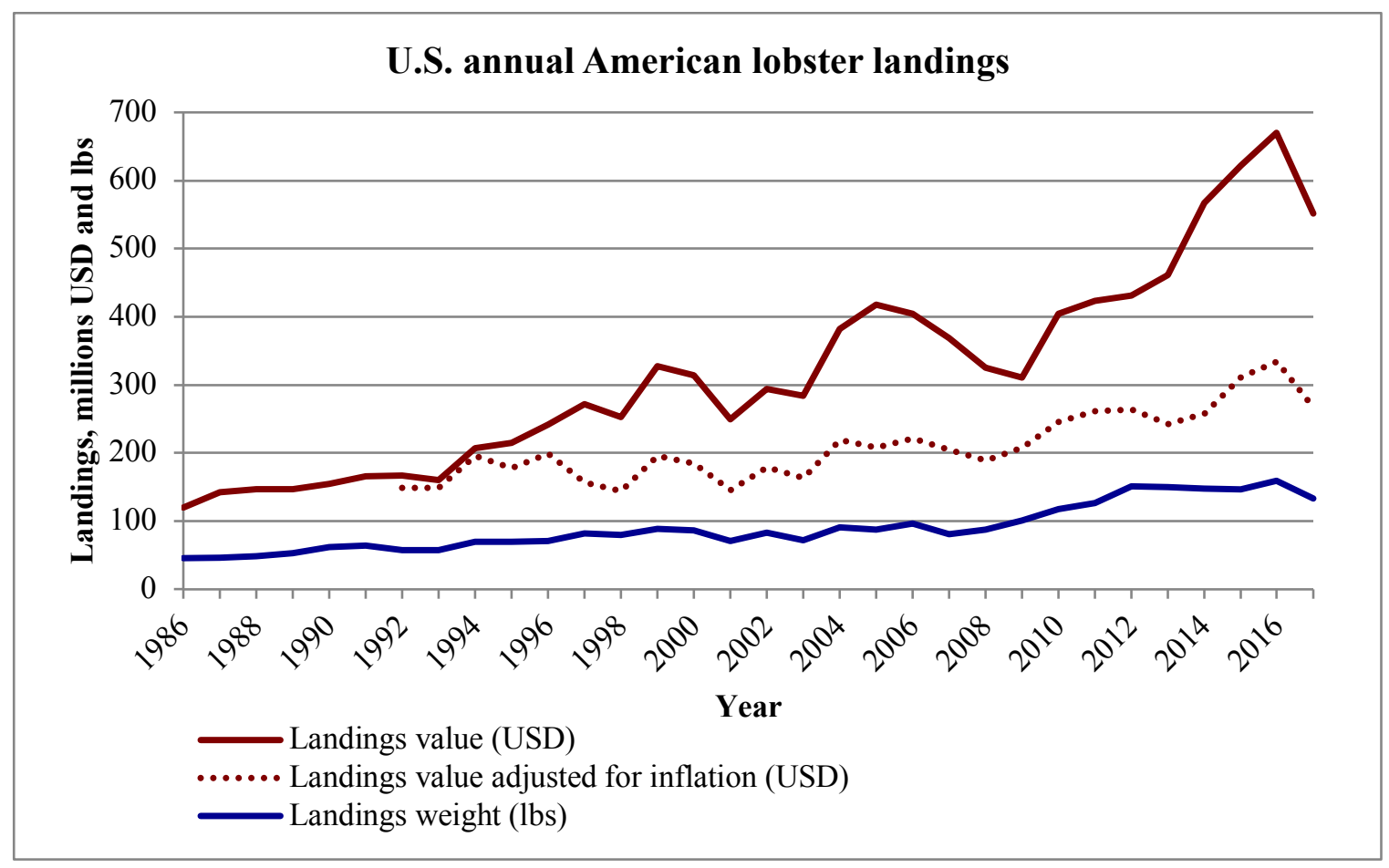

Figure 4: U.S. annual commercial lobster landings weight and value (nominal and adjusted for inflation) from 1986 to 2017. Inflation adjustment was made using the Producer Price Index (PPI) for Unprocessed Shellfish indexed to December 1991 (PPI not available for 1986 to 1991). Landings data from National Marine Fisheries Service (NMFS) Annual Commercial Landing Statistics 2019, PPI from U.S. Bureau of Labor Statistics.

This growth in landings has not been driven by a rise in the number of individuals fishing; the total number of participants in the fishery has fallen from an estimated 13,000 in 1997 to 8,485 in 2019 (NMFS 1997; NMFS 2019b). There are currently about 2,000 fishers actively operating with a federal commercial trap/pot license (GARFO American Lobster 2019); states issue the majority of licenses. NMFS issued a moratorium on new federal licenses in 1999 (NMFS 1999). Fewer fishers are bringing in significantly more revenue, although costs (especially fuel and bait) have not remained stagnant. The fishery is dominated by small owner-operated businesses.

\section{B. North Atlantic right whales}

Once numbering in the tens of thousands (Monsarrat et al. 2015), as of 2018 there were an estimated 411 North Atlantic right whales remaining (Pace et al. 2017; Pettis et al. 2018). The population grew slowly from a low of approximately 270 animals in 1990 to 482 in 2010, but has since declined rapidly (Pace et al. 2017) [Figure 5]. Only approximately 90 reproductive-aged females remain in the population (Pace et al. 2017; Hayes et al. 2018a). With continued high rates of anthropogenic mortality, the population could be functionally extinct within several decades (Meyer-Gutbrod and Greene 2018). North Atlantic right whales are protected under the U.S.'s Endangered Species Act (ESA) and Marine Mammal Protection Act (MMPA) and Canada's Species at Risk Act. 


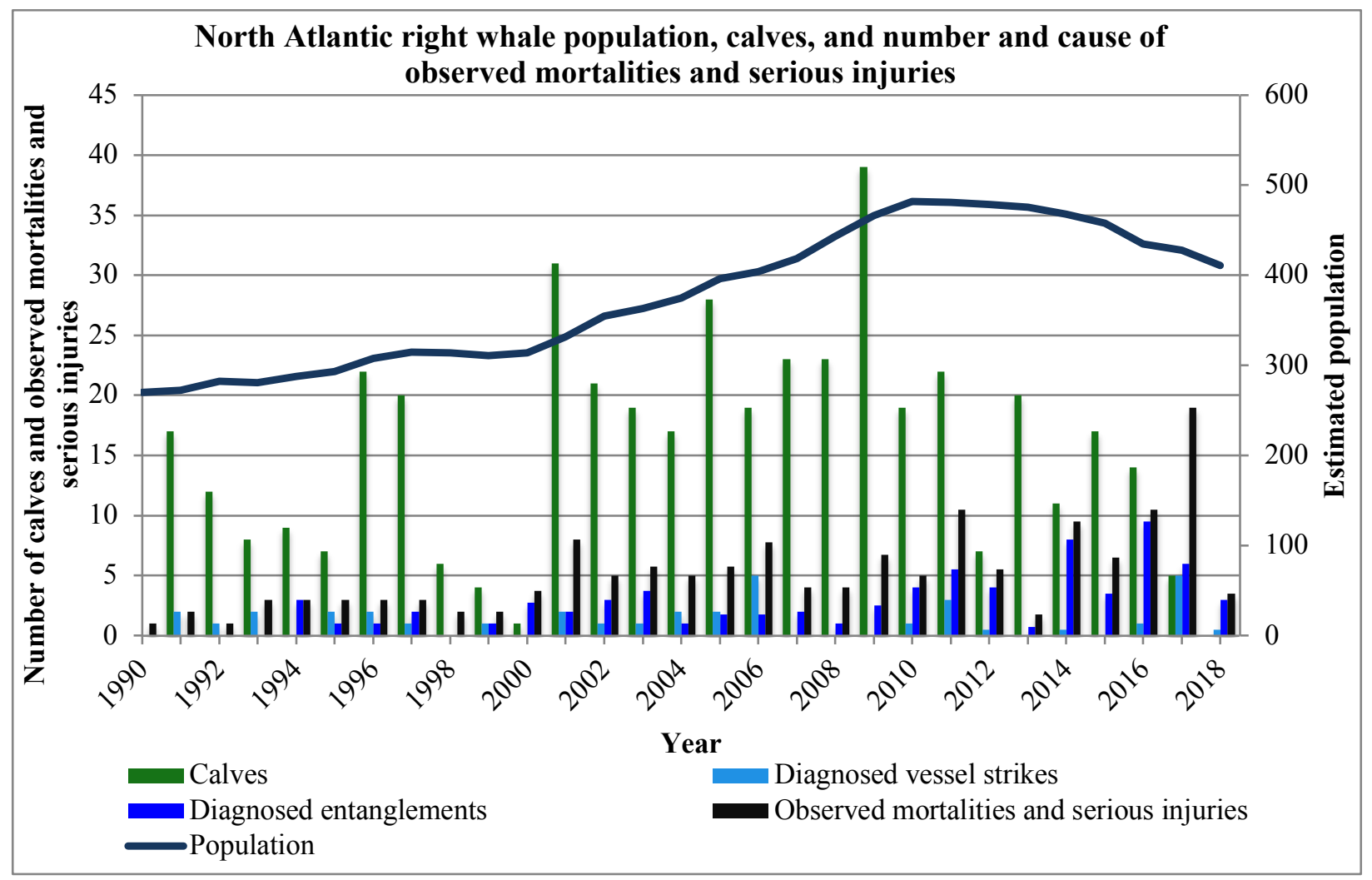

Figure 5: Estimated North Atlantic right whale population, number of calves, observed mortalities and serious injuries, and diagnosed cause of death or serious injury. Diagnosed entanglements have increased significantly since the population has been in decline. Data from Waring et al. 1997, Kraus et al. 2001, Waring et al. 2002, Moore et al. 2004, Waring et al. 2015, Pace et al. 2017, Pettis et al. 2018, Hayes et al. 2018b, and NOAA Northeast Fisheries Science Center (unpublished).

In addition to the legal imperative to conserve this species, large whales such as right whales are increasingly recognized for their important role in sequestering carbon from the atmosphere into the deep sea and in mixing and transporting nutrients to support primary productivity in marine ecosystems (Lavery et al. 2010; Pershing et al. 2010; Roman et al. 2014). A recent estimate placed the value of an average individual large whale at over US \$2 million in terms of carbon sequestration, fisheries productivity enhancement, and ecotourism (Chami et al. 2019).

Entanglement in fishing gear and vessel strikes are responsible for all diagnosed adult North Atlantic right whale mortalities since 1970; no adults are known to have died of natural causes in almost fifty years (though many mortalities are not observed or diagnosed) (Moore et al. 2004; Sharp et al. 2019). Entanglement was the cause of death in 72 percent of diagnosed adult mortalities since the population has been in decline (from 2010 to 2018), but only 35 percent from 2000 to 2009 (Moore et al. 2004; Sharp et al. 2019).

North Atlantic right whales can be found off the coast of New England and Canada in areas likely to overlap with trap/pot fisheries throughout the year (Davis et al. 2017) [Figure 6]. Rope taken off entangled whales has been tracked to fisheries throughout these areas (Hayes et al. 2018a) [Figure 7]. 

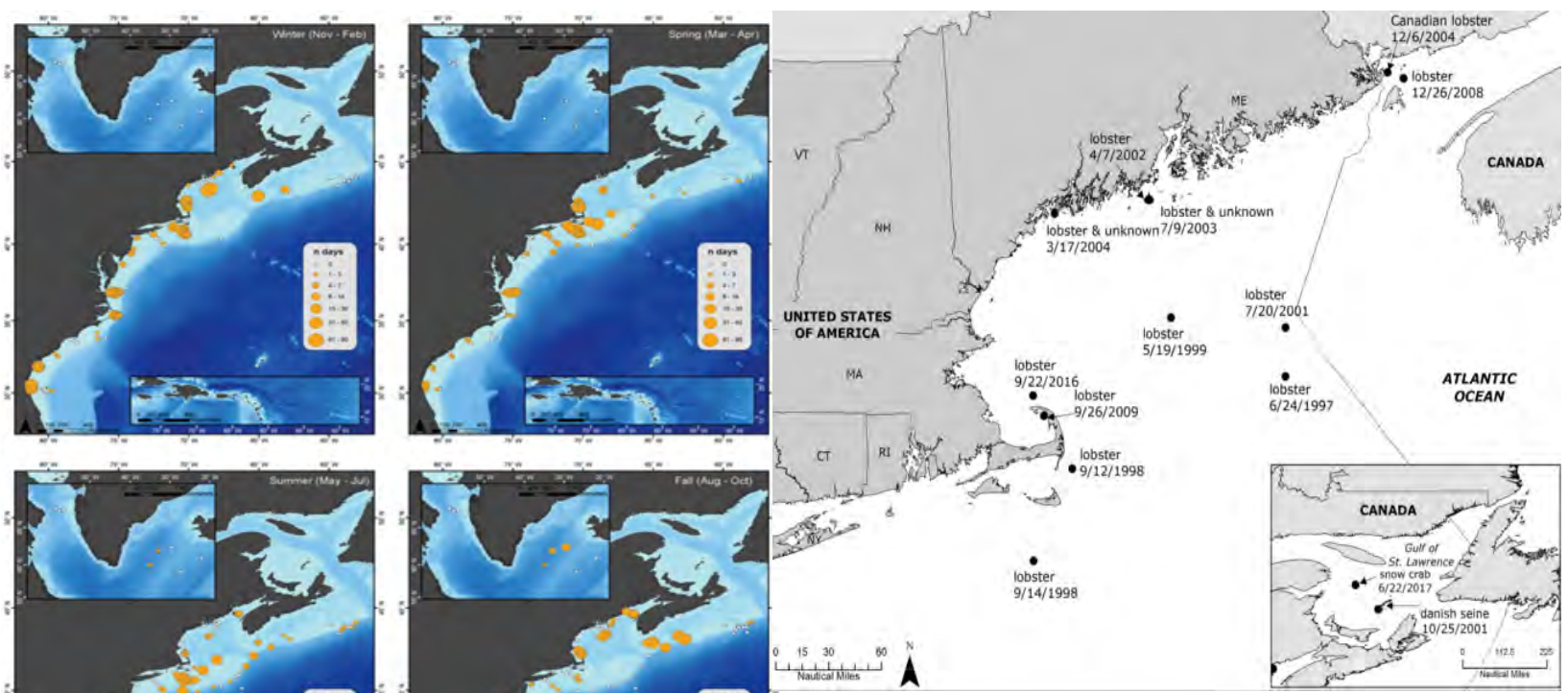

Figure 6 (left): Number of days by season with confirmed North Atlantic right whale acoustic detections from 2004 to 2014, summarized from all available acoustic recording locations. Source: Davis et al. 2017

Figure 7 (right): Map of North Atlantic right whale entanglements from 1997 to 2017 for which the set location and gear type are known and gear was recovered from a whale. Source: Hayes et al. 2018a

NMFS has calculated Potential Biological Removal (PBR) for North Atlantic right whales at 0.9, meaning that less than one animal can be killed each year due to human activity while still allowing the population to recover (Hayes et al. 2018b). Right whale serious injuries and mortalities in U.S. waters from entanglement alone-excluding entanglements known to be caused by Canadian gear-have exceeded PBR every year except for two since 2000 (Morin et al. 2018b). In their most recent ESA Section 7 consultation on the impacts of the American lobster fishery, NMFS stated that U.S. lobster fishing gear is likely to kill 3.25 animals annually (NMFS 2014). Entanglement is very common among North Atlantic right whales: in a 2012 study, 83 percent of right whales showed scars from entanglements and an estimated 26 percent_ or approximately 100 animals - are entangled each year (Knowlton et al. 2012).

In addition to mortalities, entanglement has serious sublethal impacts on North Atlantic right whales that likely inhibit the species' ability to recover (van der Hoop et al. 2017). Right whales can produce up to an estimated $8,0001 \mathrm{bs}$ of force with a single stroke of their flukes (Arthur et al. 2015), so they will often continue to swim while entangled in rope and/or associated traps and buoys. Entangling gear creates substantial drag for a swimming animal, and the energetic demands of an entanglement are comparable to or exceed those of other major life history events such as migration and pregnancy (van der Hoop et al. 2016; van der Hoop et al. 2017).

For reproductive females, the energetic costs of entanglement can extend the amount of time needed to recover fat stores following pregnancy, calving and lactation, potentially delaying the female's ability to become pregnant (van der Hoop et al. 2017). In recent years, the average calving interval for reproductive females has stretched from three to ten years (Pettis et al. 2018). Females have about a five percent chance of not becoming entangled during that ten-year period (Hayes et al. 2018a). 
Entanglement also poses a serious animal welfare concern. Beyond preventing the take of marine mammals, including North Atlantic right whales, at unsustainable levels, the MMPA also specifies that takes must be humane-wherein the term "humane" means "that method of taking which involves the least possible degree of pain and suffering practicable to the mammal involved" (MMPA 1972). When a right whale becomes entangled, the line and gear can wrap around the animal's body, flukes, flippers and mouth [Figure 8] —impeding swimming and feeding, causing chronic infection, emaciation, and damage to blubber, muscle, and bone (Moore et al. 2006; Moore and van der Hoop 2012; Moore 2013; Dolman and Moore 2017; Sharp et al. 2019) [Figure 9]. It can take months to years for a North Atlantic right whale to die of entanglement, during which time it experiences extreme pain and debilitation (Moore et al. 2006; Moore and van der Hoop 2012; Moore 2013; Moore 2014; Dolman and Moore 2017). For example, entanglement is known to have caused fatal scoliosis in a juvenile whale due to the strain of dragging fishing gear as a young animal [Figure 10] and nearly severed flippers on multiple animals swimming in up to 30 to 50 wraps of constricting rope [Figure 11] (Sharp et al. 2019).

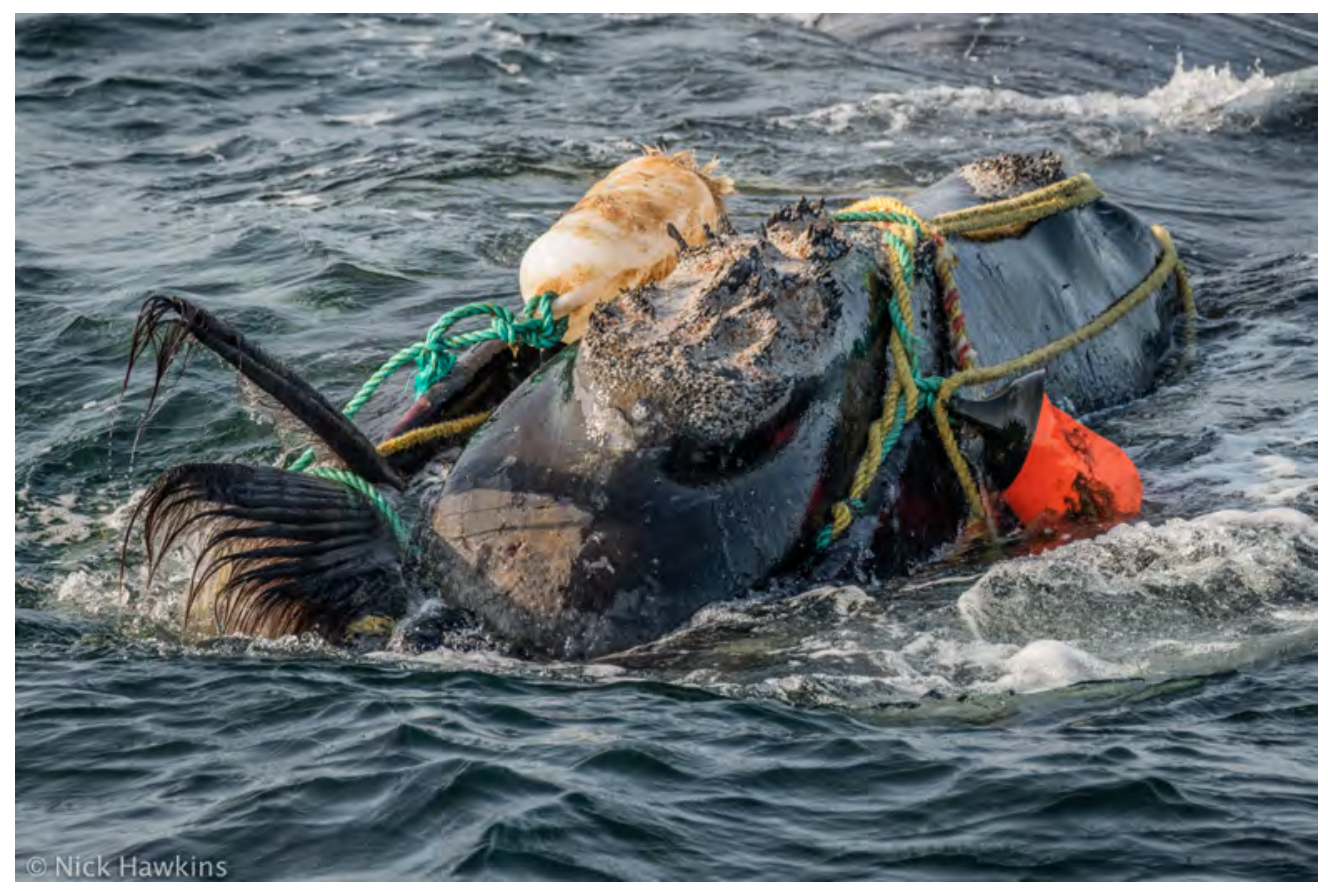

Figure 8: A live entangled North Atlantic right whale showing fishing line wraps over the blowhole and through the mouth, damaging baleen plates. Credit: Nick Hawkins 


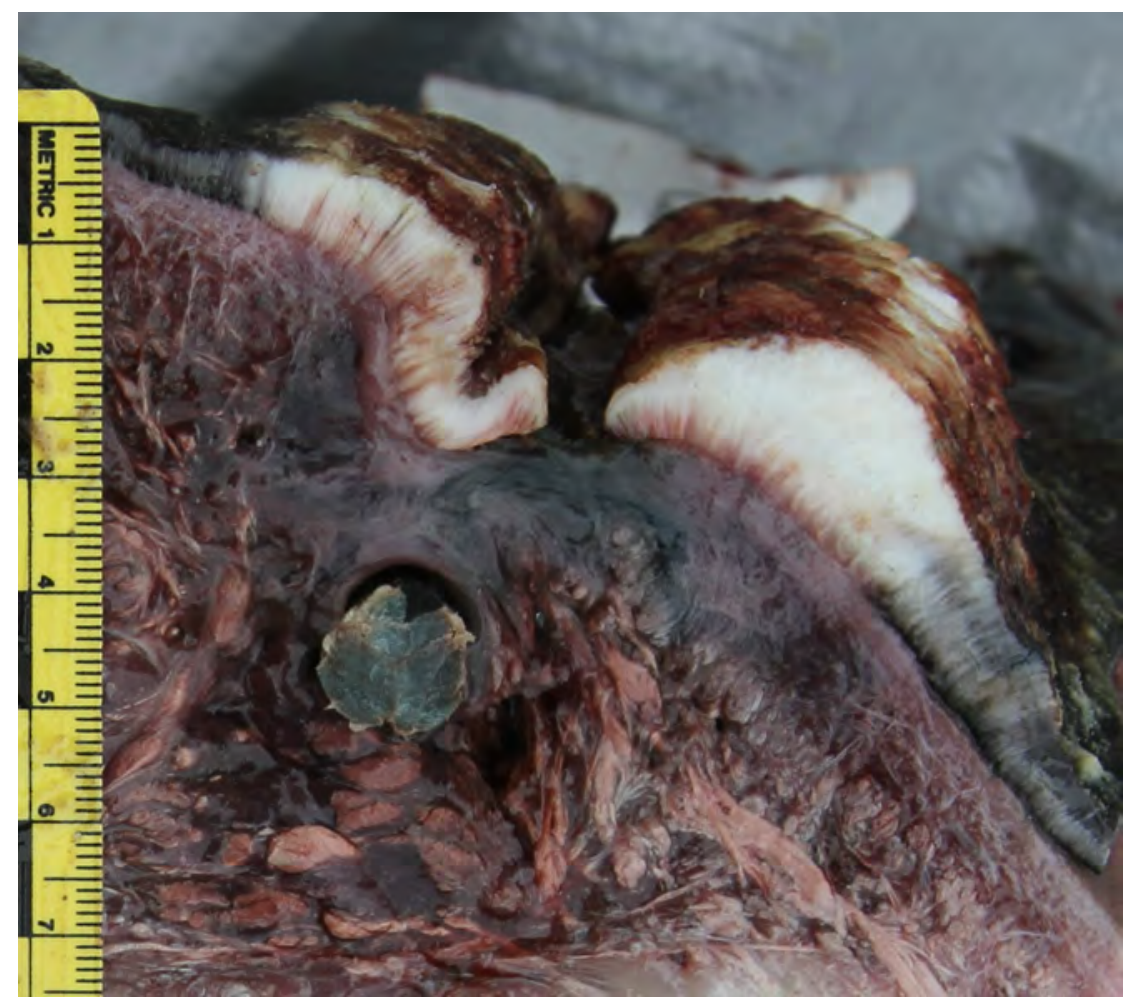

Figure 9: Fishing rope furrowed into the lip of Bayla, North Atlantic right whale \#3911. Credit: Michael Moore, NMFS Permit 932-1905-00/MA-009526

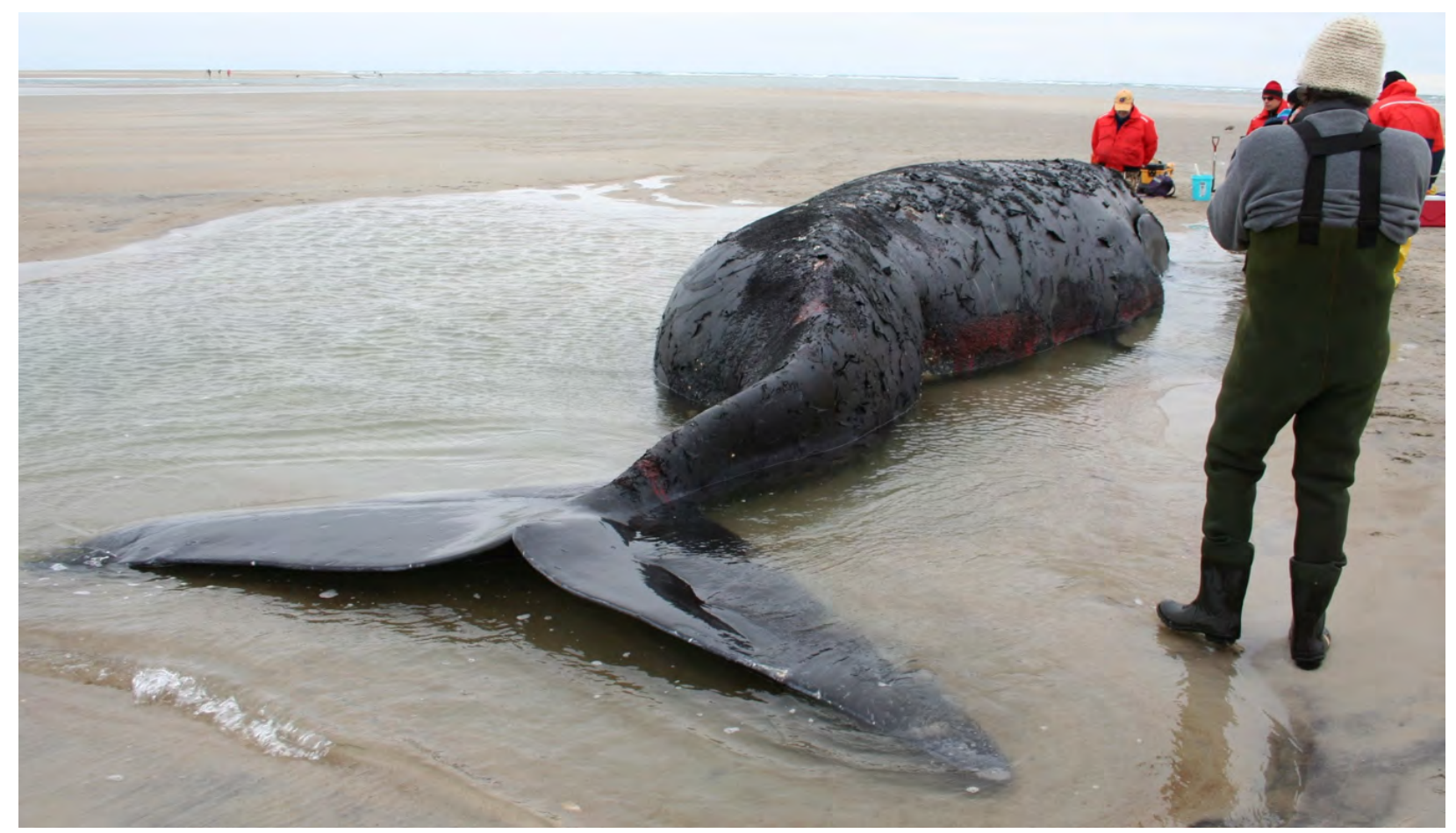

Figure 10: North Atlantic right whale (CALO0901, 3710) with debilitating abnormal curvature of the spine (scoliosis) caused by an entanglement. This injury caused chronic damage to the spine, which ultimately led to the young animal's death. Image credit: University of North Carolina Wilmington; NMFS Permit No. 932-1489. 

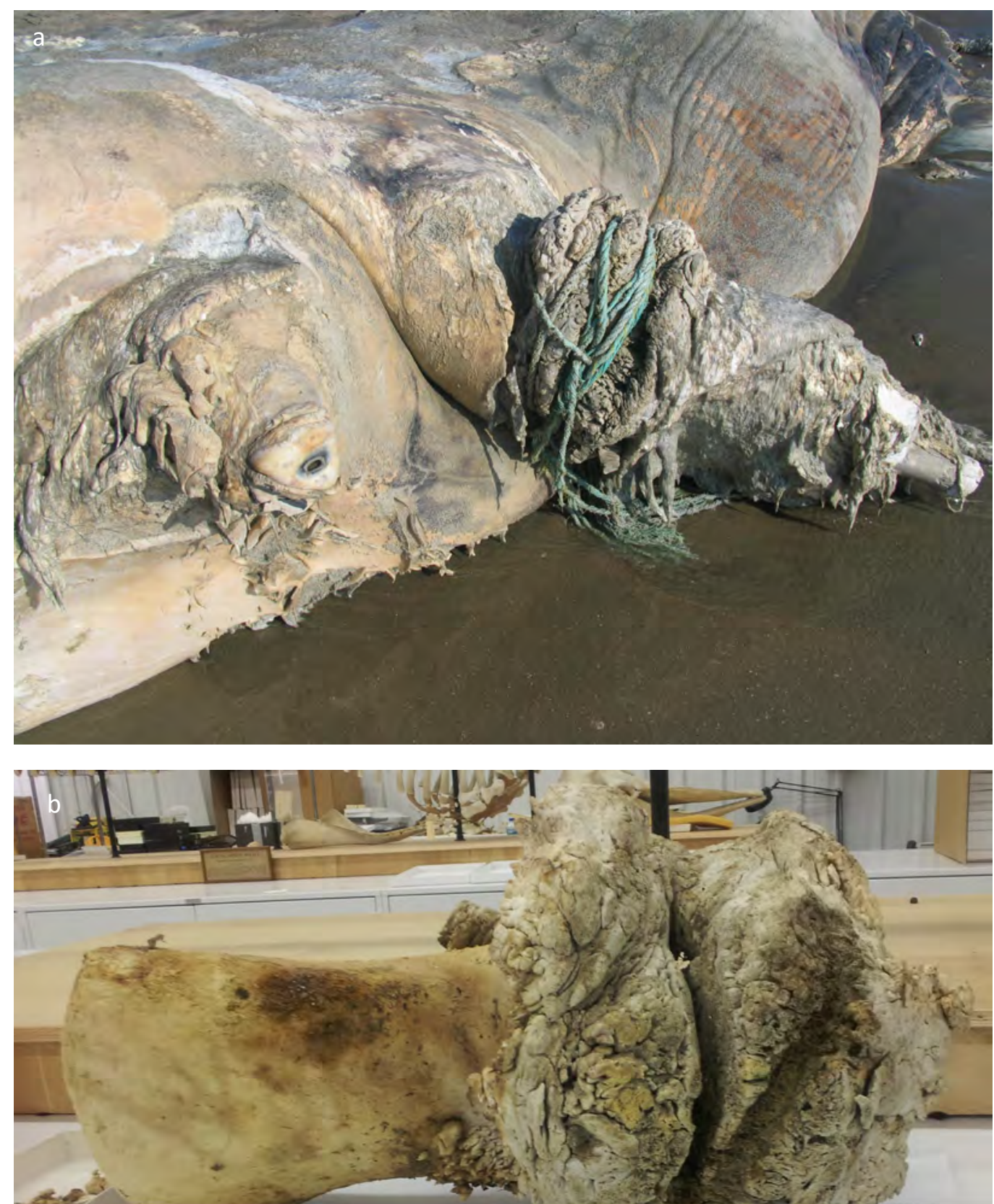

Figure 11a (top): North Atlantic right whale (SC118) with 13 constricting wraps of fishing line around a pectoral flipper that caused a partial amputation.

Figure 11b (bottom): Deep furrow created by fishing line sawing into the humerus of the same whale over time, and the bone's unsuccessful attempt to repair this injury. Image credit: NOAA National Ocean Service Center for Coastal Environmental Health and Biomolecular Research Coastal Marine Mammal Strandings and Assessments Project; NMFS Permit No. 932-1905

\section{C. Regulatory processes concerning the U.S. American lobster fishery and North Atlantic right whales}

The U.S. American lobster fishery is cooperatively managed by the states (0-3 miles from shore) and NMFS (3+ miles from shore) under the framework of the ASMFC. State waters regulations are promulgated by the respective government agencies, i.e. the Maine Department of Marine Resources and Massachusetts Division of Marine Fisheries, while complementary federal water 
regulations are promulgated by NMFS. The ASMFC assesses the fishery according to seven Lobster Management Areas (LMAs) [Figure 12], of which LMA 1 is the most productive, with 92.5 percent of total catch in 2012 (the most recent year for which landings by LMA are available) (ASMFC 2018b). Many fishers are licensed to operate in both state and federal waters; for example, 27 percent of fishers with Massachusetts state licenses also have federal licenses (Massachusetts DMF unpublished data). In cases where state and federal regulations differ, the most restrictive rule applies.

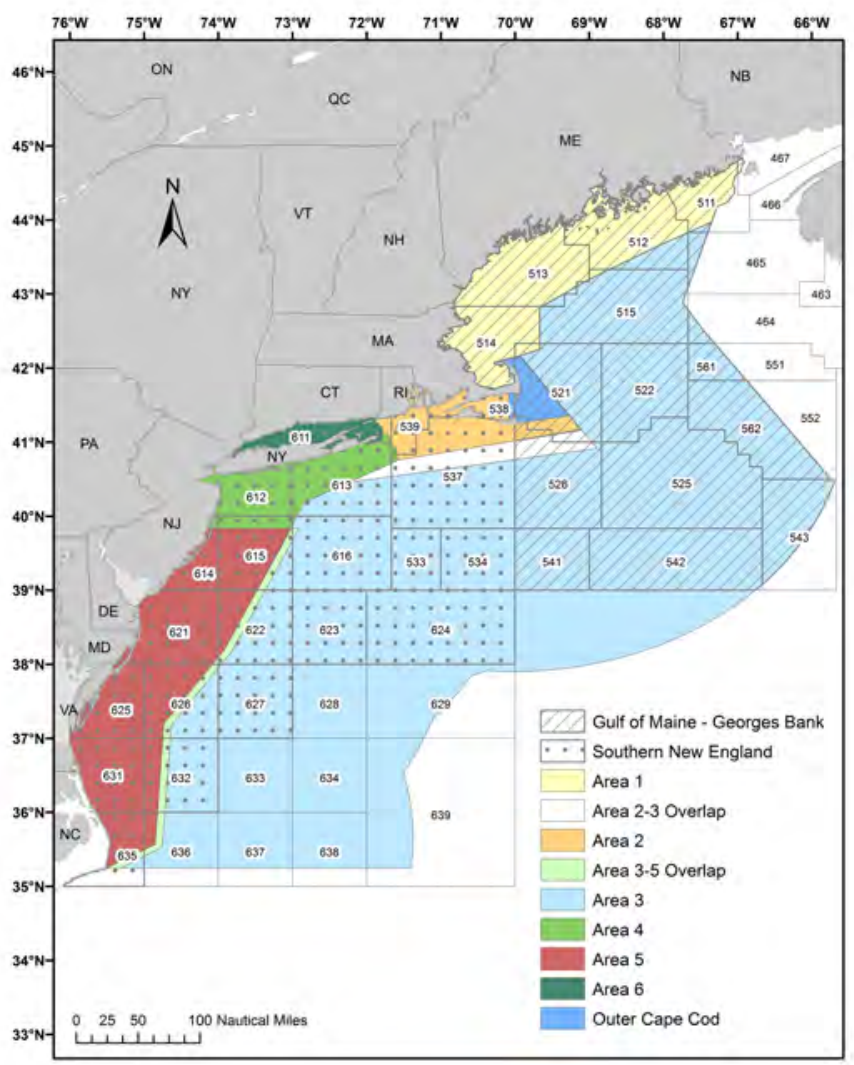

Figure 12: Map of Lobster Management Areas showing Gulf of Maine - Georges Bank and southern New England lobster stock areas, and NMFS Statistical Reporting Areas. Source: Atlantic States Marine Fisheries Commission, Map of Stock Assessment and Management Areas, available at http://www.asmfc.org/uploads/file//58f8cd9aLobste rManagement_StockArea_Map_Nov2016.JPG

The Atlantic Large Whale Take Reduction Team (ALWTRT), a group of fishers, scientists, conservationists, and state and federal officials, was created in 1996 as mandated by the Marine Mammal Protection Act to advise NMFS on steps to reduce incidental take (or killing) of large whales in Atlantic fixed gear (trap/pot and gillnet) fisheries to a level below PBR (NMFS 1997). Although the ALWTRT is mandated to reduce take of all large whale species affected by the fisheries, in recent years the ALWTRT has focused on North Atlantic right whales due to the urgency of the right whale entanglement crisis and the potential for this species to become extinct in the near future.

Since 1997, NMFS has taken a series of management actions, some of which were recommended by the ALWTRT, to identify and reduce North Atlantic right whale bycatch (Hayes 2018a). These include gear marking requirements, surface weak links, sinking groundlines, trap limits, minimum numbers of traps per endline, and seasonal fishery closures (Hayes et al. 2018a). However, right whale entanglement mortalities and serious injuries have increased substantially over the same period and the population trajectory has reversed from modest growth to rapid decline. Though a number of factors have likely contributed to the rising entanglement mortality rate, including stronger fishing rope (Knowlton et al. 2016) and climate change-related shifts in right whale distribution (Record et al. 2019), protective measures to date have failed to demonstrably reduce total right whale entanglement risk and mortalities.

Between June 2017 and September 2019, 30 North Atlantic right whales were found dead in U.S. and Canadian waters in an Unusual Mortality Event (UME) (NOAA 2019). This UME has brought renewed urgency to the ALWTRT and NMFS rulemaking processes. 
At the April 2019 ALWTRT meeting, NMFS indicated an intent to develop and implement new rules to reduce North Atlantic right whale bycatch by 60 to 80 percent and asked Team members to generate proposals to meet that risk reduction target (NMFS correspondence 2019). At the end of the meeting, the Team reached near-consensus agreement on a suite of measures implemented by state and federal management area (NMFS Key Outcomes Memorandum 2019). The primary risk reduction measures agreed upon were:

1. Reductions in the number of endlines fished by 18 to 50 percent

2. Use of reduced breaking strength (less than $1,700 \mathrm{lbs}$ force) endlines

There were notable differences in the recommendations from different caucus groups within the ALWTRT. The fishing industry and state management representatives focused on endline reductions and reduced breaking strength rope, while the conservation non-governmental organization (NGOs) members also recommended:

3. Additional time/area fishery closures in North Atlantic right whale aggregation areas

4. Rapid research using and steps toward implementation of ropeless fishing gear (defined as gear that does not use endlines prior to gear retrieval)

Additional seasonal closures and ropeless gear testing and/or implementation were not included in the near-consensus recommendations (NMFS Key Outcomes Memorandum 2019), but are likely to be continually considered as part of ongoing efforts to reduce large whale bycatch in the fishery.

The ALWTRT's near-consensus subsequently withered on August 20 ${ }^{\text {th }}, 2019$ when the Maine Lobstermen's Association withdrew their support (Maine Lobstermen's Association 2019). However, the purpose of the ALWTRT is to make consensus-based recommendations to NMFS, and under the MMPA NMFS is responsible for implementing measures to reduce serious injuries and mortalities to below PBR regardless of whether the Team reaches consensus (MMPA 1972). NMFS therefore subsequently indicated their intent to move forward with regulations (Oliver 2019). In August 2019, NMFS published a notice of intent to prepare an environmental impact statement and a request for public comments on proposed modifications to the Atlantic Large Whale Take Reduction Plan, which was based on the ALWTRT's risk reduction framework (NMFS 2019a). NMFS is tentatively expected to release a proposed rule including the ALWTRT's recommendations by early 2020, with a final rule expected thereafter.

\section{Potential impacts of proposed regulations on fishing effort}

Each of the major management measures NMFS is considering to reduce right whale bycatch could have an impact on fishing effort, described here by the number of traps or trap days used, as explained below. If the lobster fishery is operating efficiently, then a reduction in effort would likely lead to reduced landings and potentially lower revenue (depending on the extent to which price rises in response to a contraction of supply). In contrast, if the exploitation rate in the lobster fishery is above optimum efficiency, reducing effort would likely allow lobster biomass to build up so that catch rates remain high with substantially reduced operating costs (Myers et al. 2007; Worm et al. 2009). Understanding how effort reduction could impact the fishery is important for federal and state regulators, the fishing industry, and conservation interests.

1. Reductions in the number of endlines fished 
There are multiple ways in which an endline reduction can be implemented: (1) directly, such as through a vertical endline cap that could be administered similar to trap tags, and (2) indirectly, such as through a trap limit reduction combined with a set minimum number of traps per trawl. In either case, it is imperative that a vertical endline reduction be implemented as a reduction from the actual number of endlines fished, not from the amount currently allowed under regulations, for such a measure to have the expected entanglement risk reduction benefit for right whales. This is because in many areas of the fishery actual effort is lower than regulations allow. If, for example, the trap limit was reduced from 800 to 600 traps in an area where fishers use 550 traps on average, the measure would have significantly less than a 25 percent entanglement risk reduction benefit.

If a direct endline cap were to be pursued, the endline reduction would not necessarily lead to an equivalent reduction in the number of traps fished, because many fishers can add traps to trawls in order to continue fishing their standard number of traps. However, vessel and other equipment constraints would likely limit some individuals from fishing their full trap allocation. ${ }^{1}$ For example, fishers operating offshore in LMA3 often already fish long trawls of 20 or more traps and may have a limited ability to add more traps per endline. Fishers who operate on small vessels inshore may not have sufficient mechanical hauling strength to fish longer trawls. Therefore, we expect an endline cap to lead to a reduction in effort that is greater than zero but less than the amount of the endline reduction (for example, a 50 percent endline reduction will lead to a trap reduction between 0 and 50 percent). In contrast, an indirect endline reduction implemented through a trap reduction and minimum number of traps per trawl would have a direct impact on effort, provided that the reduction is from actual number of traps fished.

2. Use of reduced breaking strength (less than $1,700 \mathrm{lbs}$ force) endlines Of the proposed measures, the use of reduced breaking strength endlines has the least clear impact on effort, and may not lead to an appreciable reduction in the number of traps fished. If fishers find that $1,7001 \mathrm{~b}$ breaking strength rope cannot adequately handle their trawls as currently configured, they may consider reducing the number of traps per trawl so as to reduce the load on the endline when hauling (although there are also requirements on the minimum number of trap per trawl). However, other reconfigurations, such as lengthening the groundline between the first and second traps in a trawl, may similarly reduce the load on the endline without reducing the number of traps per trawl.

3. Additional time/area fishery closures in North Atlantic right whale aggregation areas Seasonal closures would have a direct impact on fishing effort by requiring complete removal of fishing gear from an area for a period of time. The extent to which seasonal closures will impact fishing effort depends on the duration of the closure, season, and area fished. Although fishers are currently allowed to harvest American lobster year-round other than within specific seasonal closures, there are significant differences in effort and landings by season. For example, in many areas landings are highest in the fall, while late winter and early spring bring in a significantly lower harvest (ASMFC 2015). However, some fishers keep their gear in the water even when

\footnotetext{
${ }^{1}$ Most fishers in the U.S. lobster fishery are licensed to use up to 800 traps, though there are important differences by area, especially in LMA3 where fishers may use up to 1,945 traps (GARFO American Lobster Commercial Fishing Regulations 2019).
} 
harvest is minimal, ${ }^{2}$ and endlines pose the same whale bycatch threat regardless of how much lobster is being harvested.

Neither fishing effort nor right whales are evenly distributed across the fishery; seasonal closures aim to identify areas and periods of highest risk. One particular area of concern discussed at the April 2019 ALWTRT meeting is south of Martha's Vineyard and Nantucket in NMFS Statistical Reporting Area 537 (NMFS Key Outcomes Memorandum 2019). Right whales have maintained a near-constant presence in Area 537 over the last three years and have frequently been observed aggregating in large numbers - sometimes more than 100 individuals (NOAA Right Whale Sightings Advisory System, NMFS Key Outcomes Memorandum 2019). Their presence has triggered NMFS to implement a number of successive Dynamic Management Areas, where mariners are asked (but not required) to avoid the area or reduce vessel speed to 10 knots or less (NMFS Office of Protected Resources 2019). Effort in this area is relatively low, but the offshore lobster industry operating there uses heavy fishing gear (NMFS co-occurrence model 2019; NMFS Key Outcomes Memorandum 2019).

4. Use of ropeless fishing gear

Instead of leaving an endline in the water continuously, ropeless fishing gear releases a buoy and endline or inflates a lift bag to come to the surface when a fisher sends an acoustic command to retrieve their trawl (Myers et al. 2019) [Figure 13]. Alternatively, many fishers already use a customized hook to catch the groundline between traps and haul their gear to the surface-called grappling - when the permanent buoy or endline go missing (Myers et al. 2019). Both acousticrelease ropeless fishing and grappling have the potential to substantially reduce or eliminate entanglement in endlines. Entanglement involvement with endlines is the most commonly identified interaction since the sinking groundline rule went into effect (D. Morin personal communication); since 2007, line consistent with endlines has been recovered from entangled whales about ten times more often than line consistent with groundline (Morin et al. 2018a).

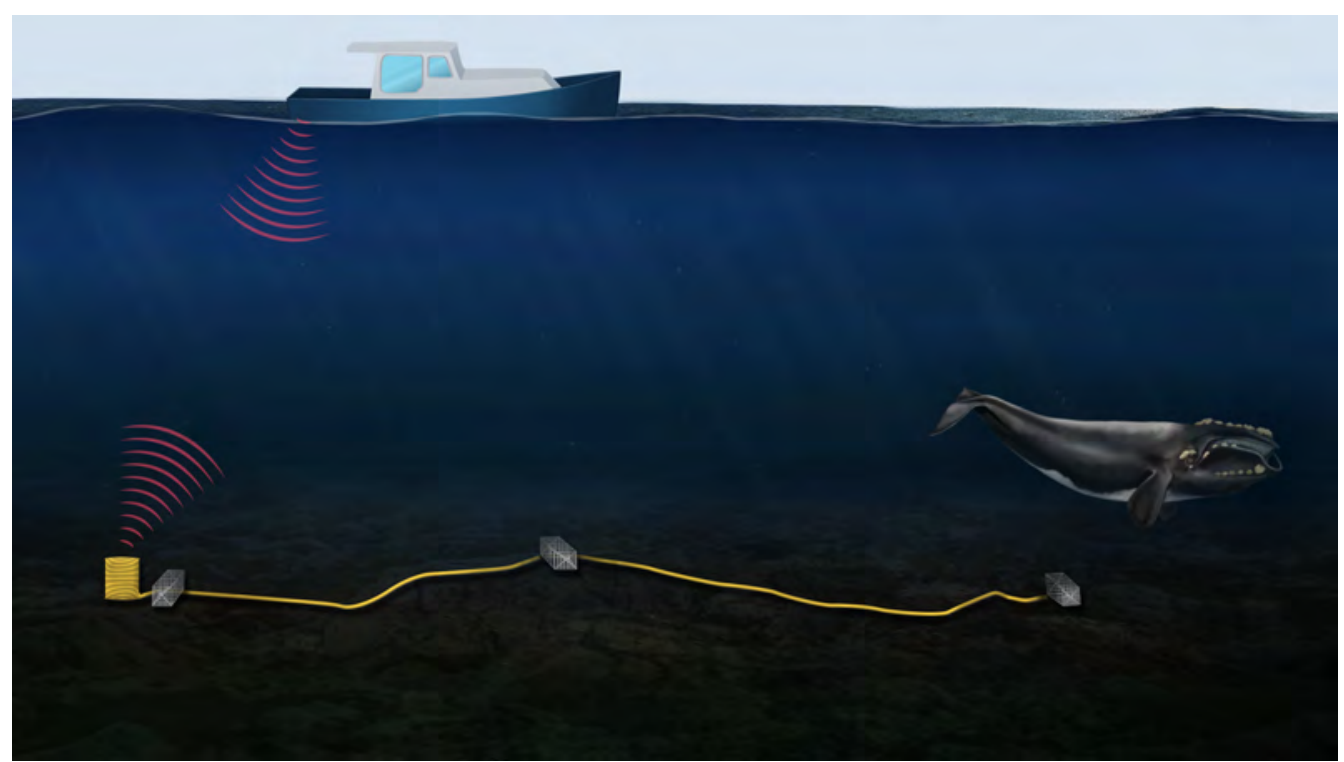

Figure 13: Illustration of acoustic-release ropeless fishing gear. Upon receiving an acoustic trigger, a buoy and

\footnotetext{
${ }^{2}$ Marine mammal regulations require that lobster traps be hauled back only once every 30 days (GARFO American Lobster Commercial Fishing Regulations 2019).
} 
endline attached to a trap at the end of a trawl deploys for retrieval or a lift bag inflates and brings the attached trap and trawl to the surface. Endlines are only used during gear retrieval, or not at all if a lift bag is used. A virtual trap marker visible on a screen in the vessel would replace the marker buoy. Credit: Natalie Renier, Woods Hole Oceanographic Institution

Ropeless fishing gear may take longer to retrieve than traditional methods due to the added time needed to triangulate on gear position using acoustic signals and/or the time needed to grapple (Myers et al. 2019). This may be particularly relevant for early adopters of ropeless gear; time costs may go down as fishers become accustomed to different retrieval methods and technologies are iteratively improved. If fishers are not able to haul as many trawls per day when fishing ropeless, ropeless fishing could effectively cause a reduction in effort. Additionally, the upfront costs of transitioning to ropeless fishing gear may be too high for fishers to replace all of their endlines at once. Combining a transition to ropeless fishing gear with an endline or trap reduction could make the upfront investment more feasible.

On the other hand, ropeless fishing could offer a solution for fishers facing an endline reduction: if allowed by federal and/or state regulations, ${ }^{3}$ fishers could replace some of their endlines with ropeless retrieval units to meet endline reduction requirements. Therefore, the overall impact of ropeless fishing on effort depends on implementation.

\section{Overcapacity and effort reduction in the U.S. lobster fishery}

We examined three case studies to describe how fishing effort has correlated with landings in the U.S. lobster fishery:

A. Comparison of lobster fishing effort on the U.S. (Maine) and Canadian (Lobster Fishing Area 34) sides of the Gulf of Maine in terms of number of traps and season days

B. State of Maine landings and number of traps over time

C. Landings within the Massachusetts Restricted Area seasonal trap/pot closure and Massachusetts statewide landings since the closure was implemented

We used publicly available ${ }^{4}$ landings data, price indices, and trap and license counts and the longest available time series up to 1986 in order to show decadal trends.

\section{A. Effort and landings in the Gulf of Maine: Maine compared to Lobster Fishing Area 34}

We employ a comparison of the lobster fishery on the U.S. and Canadian sides of the Hague Line, the North Atlantic boundary between U.S. and Canadian fishing waters, in 2016 and 2017. ${ }^{5}$

\footnotetext{
${ }^{3}$ Current federal and state regulations require the use of surface marking systems that use endlines in the American lobster fishery (GARFO American Lobster Commercial Fishing Regulations 2019). However, NMFS and some state agencies have demonstrated interest in supporting ropeless gear development and use.

${ }^{4}$ Some data sets used are not publicly published but are available upon request to the relevant state or federal agency.

${ }^{5}$ Myers et al. (2007) also employed a comparison of the U.S. and Canadian lobster fisheries across the Hague Line and found that U.S. effort was about 13 times higher than Canadian. However, Myers et al. (2007) compared landings and traps in the U.S.'s Lobster Management Area 1 and Canada's Lobster Fishing Area 34 and calculated effort using different assumptions. We chose to compare the state of Maine and LFA 34 because more recent and complete landings and effort data were available. Therefore, these two studies should not be directly compared,
} 
U.S. landings are from Maine state- and federally licensed landings from the Gulf of Maine; Canadian landings are from Lobster Fishing Area (LFA) 34 [Figure 14]. These two areas share similar biological characteristics and have both experienced record landings in recent years following four decades of landings growth (Myers et al. 2007; DFO Seafisheries Landings; NMFS Annual Commercial Landings Statistics). However, the Maine lobster fishery has a much higher trap limit and is allowed to fish year round, whereas LFA 34 is restricted to about one half of the trap limit for most Maine fishers and fishing is restricted to a winter season from the last Monday in November to May $31^{\text {st }}$ (GARFO American Lobster Commercial Fishing Regulations; DFO Integrated Fisheries Management Plan 2019).

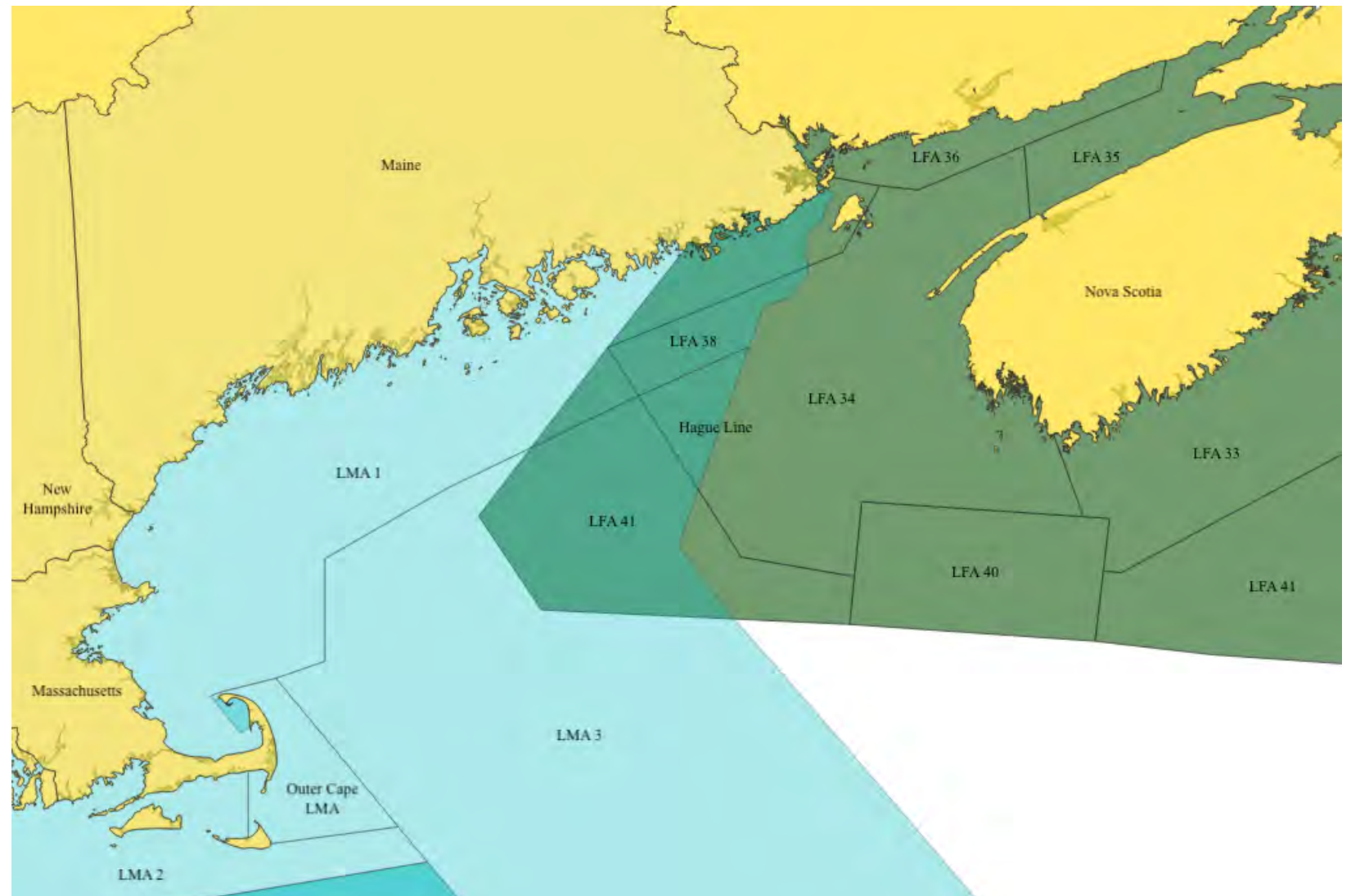

Figure 14: Map of U.S. Lobster Management Areas (LMAs) and Canadian Lobster Fishing Areas (LFAs) in the Gulf of Maine divided by the Hague Line. Maine landings and effort (primarily from LMA1 and LMA3) are compared to landings and effort in LFA 34. This map shows the U.S. definition of the Hague Line. Map created in QGIS using shapefiles from NMFS Greater Atlantic Regional Fisheries Office (Lobster Management Areas) and Free 2017 (Atlantic Coast: Lobster Fishing Areas).

To compare effort in Maine and LFA 34, we compared lobster landings, number of traps, and season days in each area in 2016 and 2017, the two most recent years for which data are available [Table 1]. LFA 34 data are provided by fishing season; in this analysis 2016 refers to the 2015/2016 fishing season and 2017 refers to the 2016/2017 fishing season. For the state of Maine, the number of traps is the number of trap tags sold, as published by the state of Maine Department of Marine Resources (Maine DMR 2019). For LFA 34, we calculated the number of

although the conclusion that the U.S. Gulf of Maine fishery is operating at substantial overcapacity holds in both assessments. 
traps as the trap limit $\left(383^{6}\right)$ multiplied by the number of licenses (979) (DFO 2019). We calculate overcapacity in Maine compared to LFA 34 as:

Overcapacity in Maine versus LFA $34=$ (number of traps $\mathrm{x}$ season days) / landings

Lobster Fishing Effort in Maine versus Lobster Fishing Area 34, 2016

\begin{tabular}{lllc}
\hline & Maine & LFA 34 & Maine/LFA 34 \\
\hline $\begin{array}{l}\text { Landings (metric } \\
\text { tons) }\end{array}$ & 60,175 & 29,151 & 2.06 \\
Number of traps & $2,946,000$ & 375,000 & 7.86 \\
$\begin{array}{l}\text { Season days } \\
\begin{array}{l}\text { Overcapacity in } \\
\text { Maine versus LFA }\end{array}\end{array}$ & 365 & 184 & 1.98 \\
$\mathbf{3 4}$ & & 7.55 \\
\hline
\end{tabular}

Table 1A: Landings, number of traps, and season days in Maine versus Lobster Fishing Area (LFA) 34 in 2016 (LFA 34's 2015/2016 fishing season). Maine fishers used approximately 7.55 times as much effort as fishers in LFA 34 to harvest the same amount of lobster. Maine landings data from National Marine Fisheries Service Annual Commercial Landings Statistics and number of traps from Maine Department of Marine Resources Historical Maine Lobster Landings. LFA 34 landings, number of licenses, trap limits, and season days from Fisheries and Oceans Canada March 2019 update to the Integrated Fisheries Management Plan for LFAs 27-38.

Lobster Fishing Effort in Maine versus Lobster Fishing Area 34, 2017

\begin{tabular}{lllc}
\hline & Maine & LFA 34 & Maine/LFA 34 \\
\hline $\begin{array}{l}\text { Landings (metric } \\
\text { tons) }\end{array}$ & 48,983 & 22,679 & 2.16 \\
Number of traps & $2,954,000$ & 375,000 & 7.88 \\
$\begin{array}{l}\text { Season days } \\
\begin{array}{l}\text { Overcapacity in } \\
\text { Maine versus LFA }\end{array}\end{array}$ & 365 & 185 & 1.97 \\
$\mathbf{3 4}$ & & 7.20 \\
\hline
\end{tabular}

Table 1B: Landings, number of traps, and season days in Maine versus Lobster Fishing Area (LFA) 34 in 2017 (LFA 34's 2016/2017 fishing season). Maine fishers used approximately 7.20 times as much effort as fishers in LFA 34 to harvest the same amount of lobster. Maine landings data from National Marine Fisheries Service Annual Commercial Landings Statistics and number of traps from Maine Department of Marine Resources Historical Maine Lobster Landings. LFA 34 landings, number of licenses, trap limits, and season days from Fisheries and Oceans Canada March 2019 update to the Integrated Fisheries Management Plan for LFAs 27-38.

In Maine, fishers use nearly eight times as many traps to catch about twice as much lobster as fishers in LFA 34 [Table 1]. Since the lobster fishing season in Maine is almost twice as long as that in LFA 34, we calculate that effort in Maine is approximately 7.5 times higher than that in

\footnotetext{
${ }^{6}$ The trap limit in LFA 34 is 375 for approximately two thirds of the season and 400 for one third of the season (DFO 2019). We therefore used a scaled trap multiplier of 383.
} 
LFA 34 to harvest the same amount of landings. Results were comparable from 2016 to 2017, as both areas experienced a drop in landings of about 20 percent.

It is important to note that many Maine fishers do not actively fish during the full 365-day season, and commonly remove gear for part of the year. However, even if we estimate that Maine fishers use 75 percent of available fishing days (292 days), capacity in Maine is still about 5.5 times that in LFA 34. Additionally, the number of trap tags sold in Maine does not fully account for latent effort; some fishers likely do not use all of the trap tags they purchase. However, the number of trap tags sold is markedly lower than the full trap limit. In 2016 and 2017, the number of trap tags sold averaged 490 and 493 per fisher, respectively (Maine DMR 2019), whereas the trap limit is 800 in most areas. This indicates that the number of trap tags sold is a better indicator for actual effort than the number of licenses multiplied by the trap limit in Maine. In contrast, the number of traps for LFA 34 calculated here represents the upper bound for this area and assumes all license holders fish the full trap limit. ${ }^{7}$

Even if latent effort in Maine is approximately 20 percent of the number of trap tags sold and Maine fishers actively fish 75 percent of the year, overcapacity in Maine compared to LFA 34 is 4.5 times. ${ }^{8}$ Even a much lower overcapacity estimate would indicate that effort reduction measures currently under consideration by NMFS (i.e. an endline and possible trap reduction of up to 50 percent) would likely benefit the fishery.

Next, we calculated landings per trap in Maine compared to LFA 34 [Table 2]. Total landings indicate a fisher's revenue (when multiplied by ex-vessel price), and does not account for cost. In contrast, landings per trap is a stronger proxy for profit than total landings because it partially accounts for costs by standardizing to effort. Bait and fuel are frequently the most significant input costs to harvest lobster, and are closely related to the number of traps used (i.e. each trap is baited, and fishers likely travel farther and use more fuel to haul more traps). To calculate landings per trap, we divided total annual landings by the number of traps from Table 1.

Landings per trap in Maine versus Lobster Fishing Area 34

\begin{tabular}{llll}
\hline & $\begin{array}{l}\text { Maine landings per } \\
\text { trap (lbs) }\end{array}$ & $\begin{array}{l}\text { LFA 34 landings } \\
\text { per trap (lbs) }\end{array}$ & LFA 34/ Maine \\
\hline $\mathbf{2 0 1 6}$ & 45 & 171 & 3.8 \\
$\mathbf{2 0 1 7}$ & 37 & 133 & 3.6 \\
\hline
\end{tabular}

Table 2: Landings per trap in Maine compared to Lobster Fishing Area (LFA) 34 in 2016 and 2017 (LFA 34's 2015/2016 and 2016/2017 fishing seasons, respectively). LFA 34 fishers harvested about 3.7 times as much lobster per trap as Maine fishers. Maine landings data from National Marine Fisheries Service Annual Commercial Landings Statistics and number of traps from Maine Department of Marine Resources Historical Maine Lobster Landings. LFA 34 landings, number of licenses, trap limits, and season days from Fisheries and Oceans Canada March 2019 update to the Integrated Fisheries Management Plan for LFAs 27-38.

In 2016 and 2017, LFA 34 fishers brought in about 3.7 times as much lobster per trap than Maine fishers (3.8 times in 2016 and 3.6 times in 2017). This calculation of landings per trap does not take season days into account. Again, if latent effort in Maine is approximately 20 percent of the

\footnotetext{
${ }^{7}$ LFA 34 license holders are issued a yearly set of trap tags which matches the trap limit, they do not select a number of trap tags to purchase each year (Fisheries and Oceans Canada March 2019 update to the Integrated Fisheries Management Plan for LFAs 27-38).

87.5 x .80 x.75=4.5 times overcapacity in Maine compared to Lobster Fishing Area 34
} 
number of trap tags sold, LFA 34 landings per trap are still three times higher than in Maine, assuming all LFA 34 fishers use the full trap limit.

LFA 34 did not achieve high landings in recent years by increasing effort; the number of lobster licenses and trap limit has remained consistent over time [Figure 14] (Myers et al. 2007; DFO 2011; DFO Atlantic Region Licenses). Therefore, landings per trap (a proxy for profit) in LFA 34 mirrored growth in total landings [Figure 15]. In contrast, the number of traps in Maine increased for much of the last three decades [Figure 14] (Maine DMR 2019), likely indicating comparably higher costs and lower profits during a similar period of landings growth [Figure 15]. We compared the number of lobster traps in Nova Scotia Maritimes and Maine from 1990 to 2017 to illustrate this concept. Here we switch to Nova Scotia Maritimes because a more consistent time series of the number of licenses is available (DFO Atlantic Region Licenses). LFA 34 is the most significant contributor to total Nova Scotia Maritimes landings. The number of traps in Nova Scotia Maritimes was calculated by multiplying the annual number of licenses by the proportion of licenses per LFA, category, and LFA restrictions from the most recent Integrated Fisheries Management Plan from 2011 (DFO 2011).

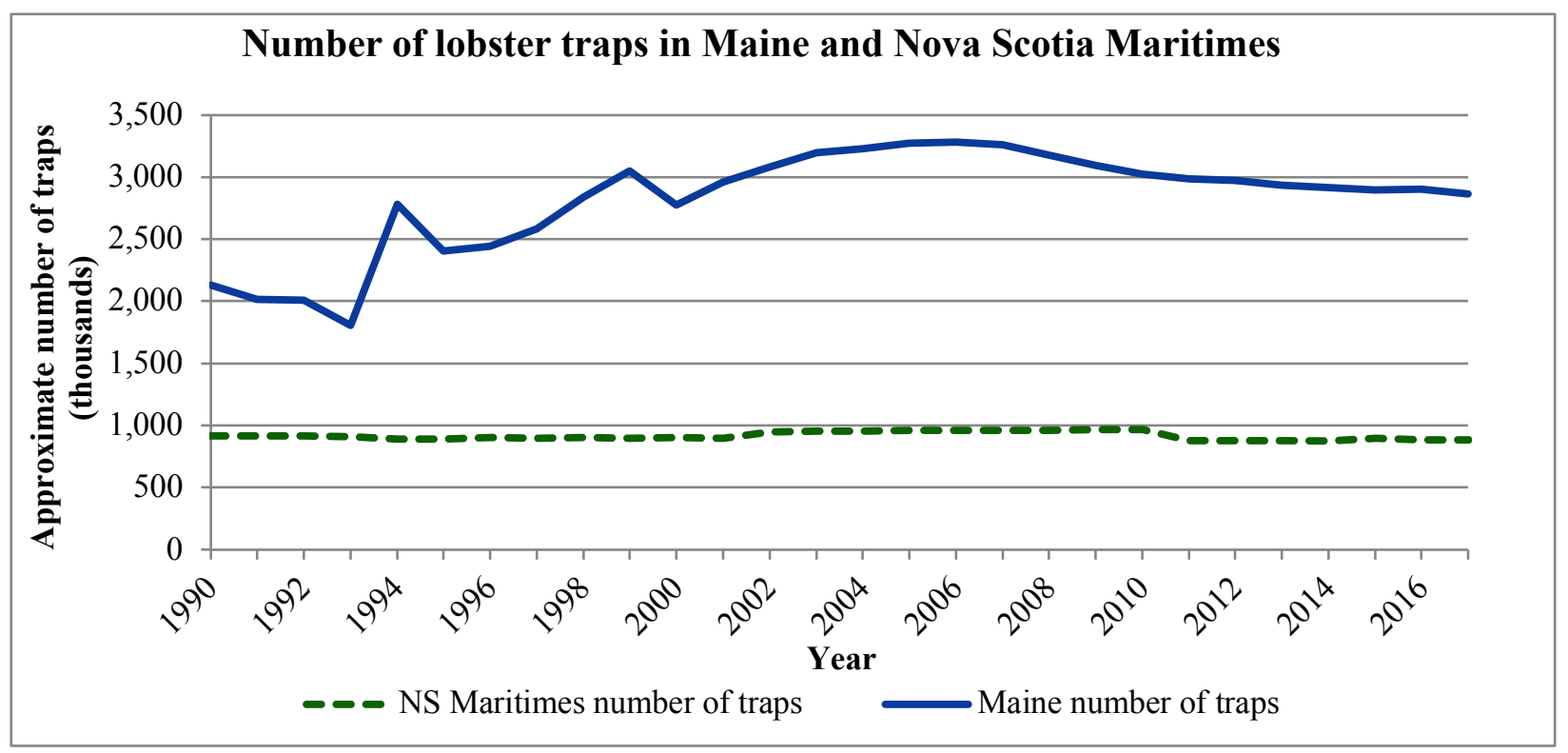

Figure 14: Estimated number of lobster traps in Maine versus Nova Scotia (NS) Maritimes from 1990 to 2017. Maine number of traps showed uneven growth until reaching a peak of 3.283 million traps in 2006 and has since tapered off slightly, while NS Maritimes number of traps has remained relatively consistent at approximately 900,000 traps. Data from Maine Department of Marine Resources Historical Maine Lobster Landings, DFO Integrated Fisheries Management Plan for LFAs 27-38 (2011), and DFO Atlantic Region Licenses. 


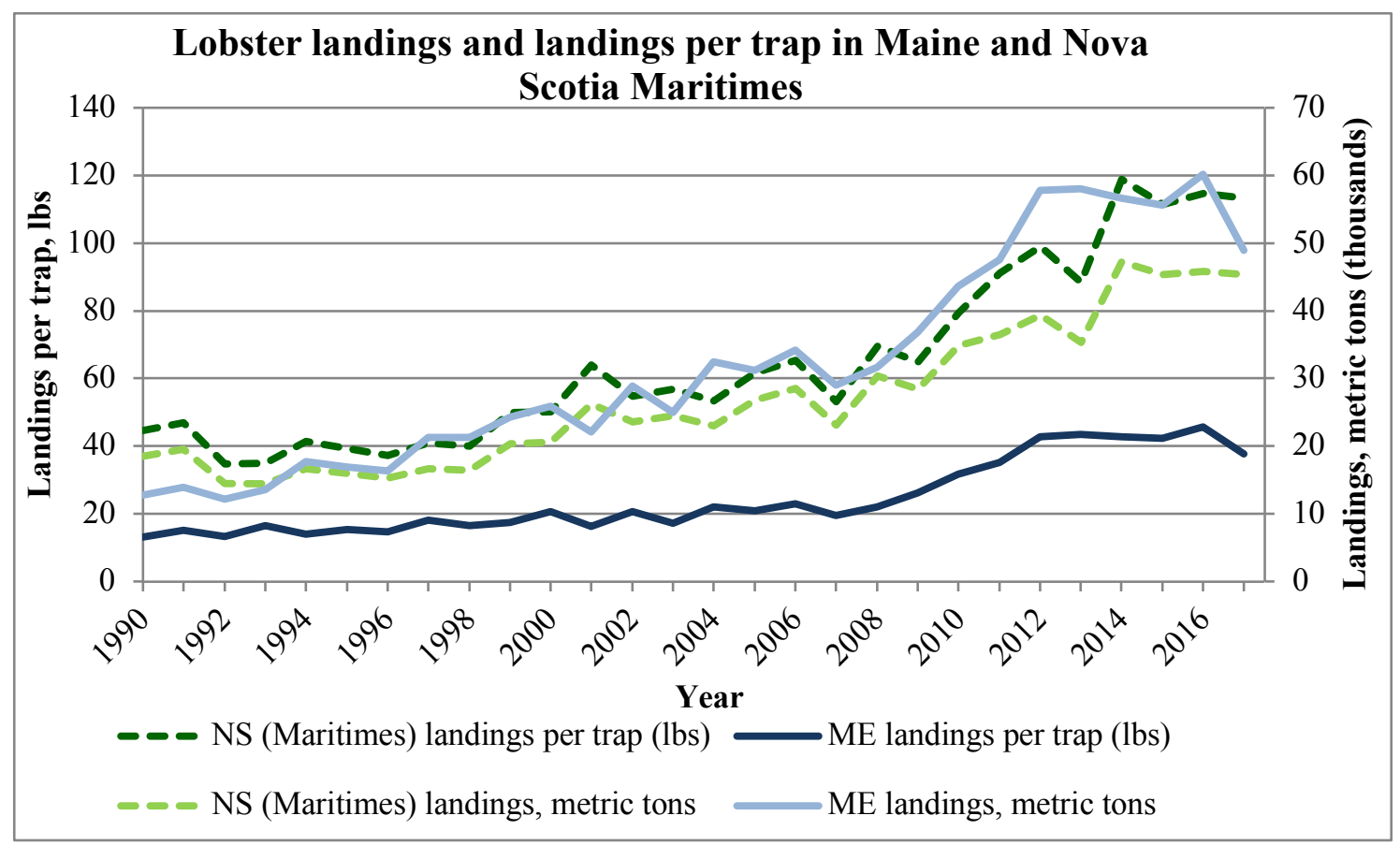

Figure 15: Maine and Nova Scotia (NS) Maritimes lobster landings and landings per trap from 1990 to 2017. While NS Maritimes landings per trap mirrored landings growth, Maine landings per trap remained relatively stagnant for the majority of this period. Data from DFO Seafisheries Landings, DFO Atlantic Region Licences, DFO Integrated Fisheries Management Plan for LFAs 27-38 (2011), NMFS Annual Commercial Landings Statistics, and Maine Department of Marine Resources Historical Maine Lobster Landings.

Landings per trap is especially relevant as per trap harvesting costs, especially bait, are expected to rise in the near future. For example, from 2018 to 2019 the U.S. Atlantic herring quota was cut by 80 percent and is expected to remain low in coming years (NMFS 2019c). Because herring has been the most important American lobster bait, the reduced quota could cause bait shortages and higher prices in the near-term, increasing per trap lobster harvesting costs (though other bait alternatives may mitigate higher costs) (NMFS 2019c).

\section{B. Maine landings and number of traps over time}

Maine is the largest contributor to the American lobster fishery, with fishers in the state bringing in 83.3 percent of total U.S. catch in 2016 (NMFS Annual Commercial Landings Statistics). The Maine Department of Marine Resources maintains a database of historical Maine lobster landings that details the number of traps in the fishery (Maine DMR 2019). ${ }^{9}$ The number of traps used by Maine lobster fishers grew through the late 1980s and 90s to reach a high in 2006 of 3.283 million traps, and has since tapered off [Figure 16]. Landings have shown strong growth throughout, driving the overall growth in the U.S. lobster fishery despite the collapse of the southern New England stock since the late 1990s [Figure 16] (ASMFC 2015).

\footnotetext{
${ }^{9}$ From 1981 to 1995 , DMR calculated the number of traps used by estimating the number of active boats and mean traps per harvester. From 1996 to 2016 the number of traps was taken from the number of trap tags sold.
} 


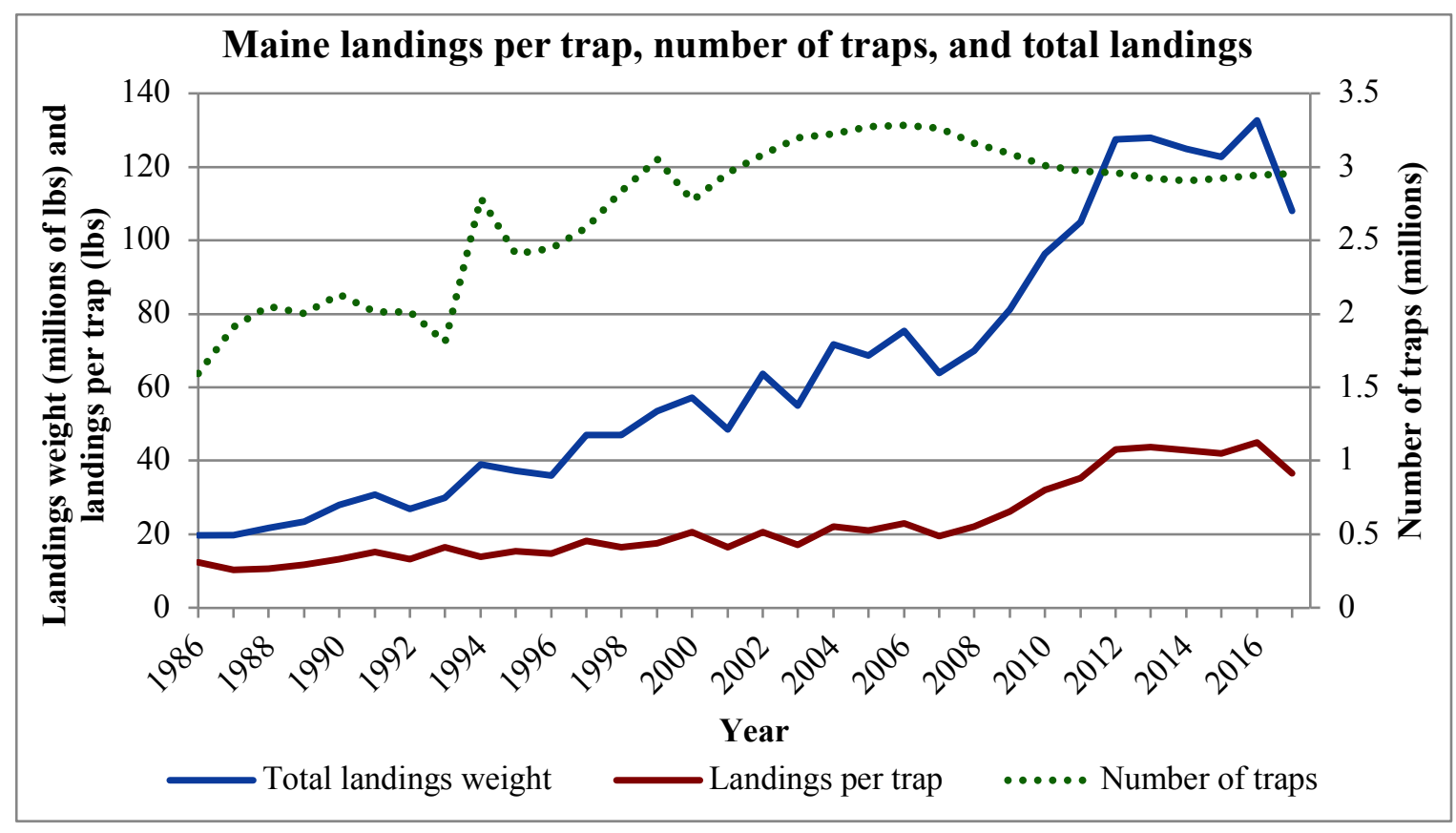

Figure 16: Maine lobster landings per trap, number of traps (an upper bound indicated by the number of trap tags sold), and total landings weight from 1986 to 2017. Landings per trap were relatively stagnant except from 2007 to 2013, when landings per trap increased substantially year on year, correlating with a decrease in the number of traps and faster rate of growth in total landings. Data from National Marine Fisheries Service Annual Commercial Landings and Maine Department of Marine Resources Historical Maine Lobster Landings.

Although many factors impact landings, historically a reduction in number of traps has not been connected to reduced landings in Maine. Landings per trap have been relatively stagnant in Maine for most of the last three decades, except for a period from 2007 to 2013 when landings per trap grew rapidly year on year. During this period, landings per trap grew 124 percent from $19.6 \mathrm{lbs}$ to $43.8 \mathrm{lbs}$. This growth in landings per trap correlates with a 10.5 percent decrease in number of traps and a doubling in landings (100.2 percent increase). As discussed above (section $3 \mathrm{~A}$ ), landings per trap is a better proxy for fishing profit than landings alone. The rate of growth of total landings weight was also faster after trap numbers began to fall: from 2007 to 2016 Maine landings grew by 207 percent, whereas from 1997 to 2006 landings grew by 160 percent, and landings grew by 183 percent in the decade prior. Such a correlation between reduced effort and increased landings is characteristic of an overexploited fishery.

\section{C. Massachusetts landings before and after implementation of the Massachusetts Restricted Area trap/pot seasonal closure}

In 2015, NMFS expanded trap/pot seasonal closures in the Massachusetts Restricted Area and the Great South Channel to protect significant aggregations of North Atlantic right whales known to feed in these areas each year [Figure 17] (NMFS 2014b). The Massachusetts Restricted Area is closed to trap/pot fishing from February $1^{\text {st }}$ to April $30^{\text {th }}$ and the Great South Channel is closed to trap/pot fishing from April $1^{\text {st }}$ to June $30^{\text {th }}$ (NMFS 2014b). In 2017, 2018, and 2019, the Massachusetts Division of Marine Fisheries extended the closure in Cape Cod Bay by up to 14 days due to the continued presence of endangered right whales (Massachusetts DMF 2017; 2018; 2019). We focus on the Massachusetts Restricted Area closure in this study because it fully covers multiple Statistical Reporting Areas, making it more feasible to discern the change 
in landings since the closure was implemented, and because the Massachusetts Restricted Area contributes a greater portion of total statewide landings.

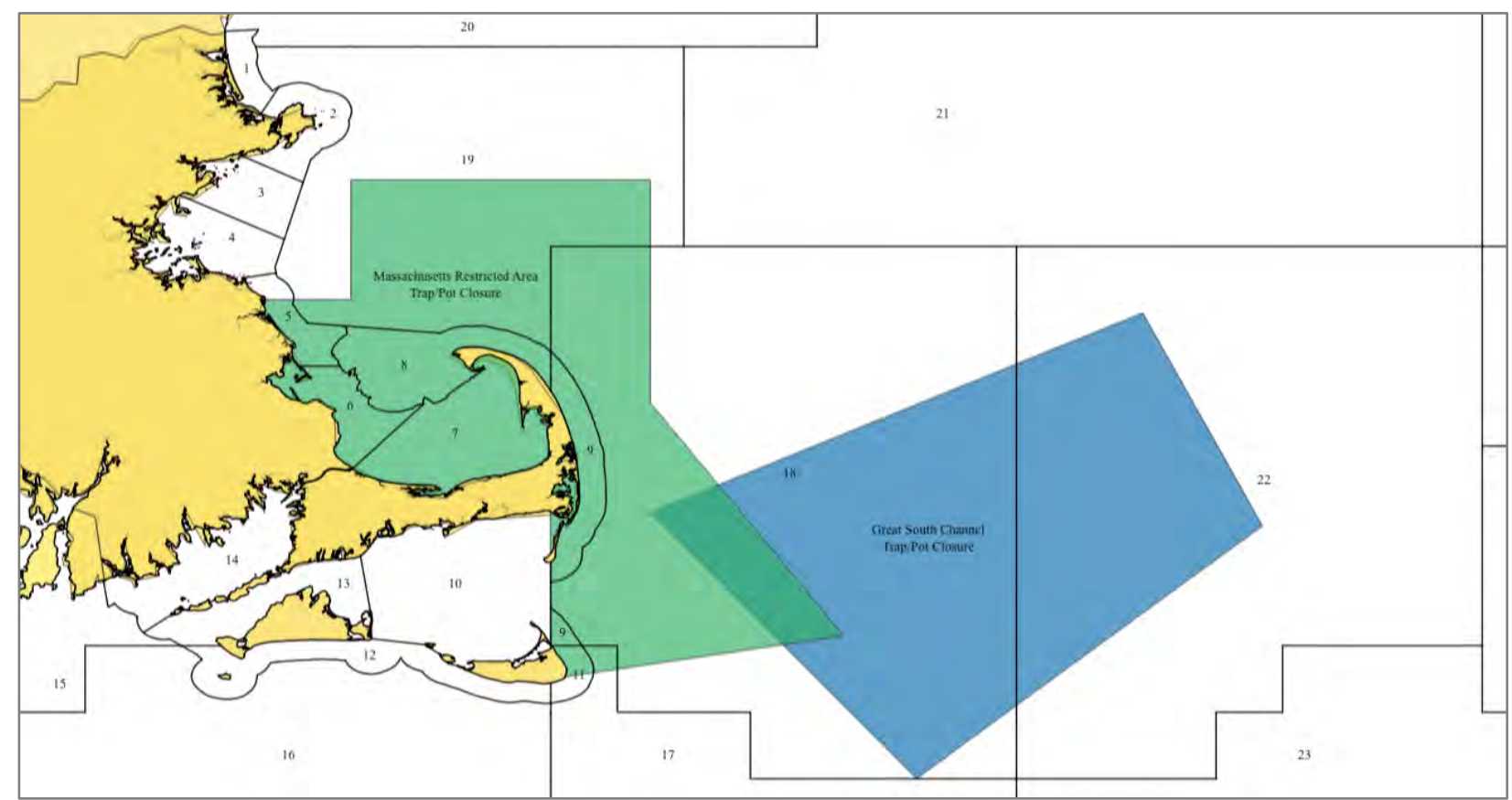

Figure 17: Map showing the Massachusetts Restricted Area (green) and Great South Channel (blue) Trap/Pot Closures and Massachusetts lobster harvesting Statistical Reporting Areas (SRAs). The Massachusetts Restricted Area closure includes all of SRAs 6, 7, 8, and 9 and most of SRA 5, as well as portions of SRA 18 and 19. The Great South Channel is located within SRAs 18 and 19. Map created in QGIS using shapefiles from NMFS Greater Atlantic Regional Fisheries Office (Great South Channel Restricted Trap/Pot Area and Massachusetts Restriced Area) and MassGIS Bureau of Geographic Information (Lobster Harvest Zones, State Outline, and New England).

These Massachusetts Restricted Area closure primarily impacts Massachusetts-based fishers, especially those fishing Massachusetts' south shore, Cape Cod Bay, and the outer Cape, though the exact number of fishers affected is unclear. In an amendment to the final rule establishing the trap/pot fishery closure published in 2014, NMFS estimated that "slightly more than" 125 fishers would be affected by the Massachusetts Restricted Area closure (NMFS 2014b). The Massachusetts Division of Marine Fisheries (DMF) has identified 172 individuals who previously fished in Statistical Reporting Areas that fall within the Massachusetts Restricted Area during February, March, and April who can no longer do so (Massachusetts DMF unpublished data). Representatives of the fishing industry have recently estimated that 250 fishers are affected (Casoni 2018). In 2017, there were 1,018 commercial lobster permits licensed in Massachusetts, of which approximately 780 are actively fished (Massachusetts DMF unpublished data). Therefore, according to these estimates the Massachusetts Restricted Area closure affects between 16 and 32 percent of Massachusetts' active lobster fishers.

Since the seasonal closures last at least three months, fishers who are impacted often publicly state that they lose at least one quarter of their income each year due to the closures (Abel 2019a; Abel 2019b). Some fishers claim that the three-month closure effectively becomes five months, causing them to lose closer to 40 percent of their annual income because it takes about one month to remove their traps before the February $1^{\text {st }}$ start date and another month to replace them once the fishery reopens (Abel 2019a; Abel 2019b; Casoni 2019). However, in the three years 
for which Vessel Trip Report data are available since the closure was implemented $(2015,2016$, and 2017), lobster landings in the Statistical Reporting Areas (SRAs) covered by the closures have continued to grow to record highs [Figure 18] (Massachusetts DMF unpublished data). Vessel Trip Reports are collected for all commercial vessels fishing in Massachusetts waters (ASMFC 2018a).

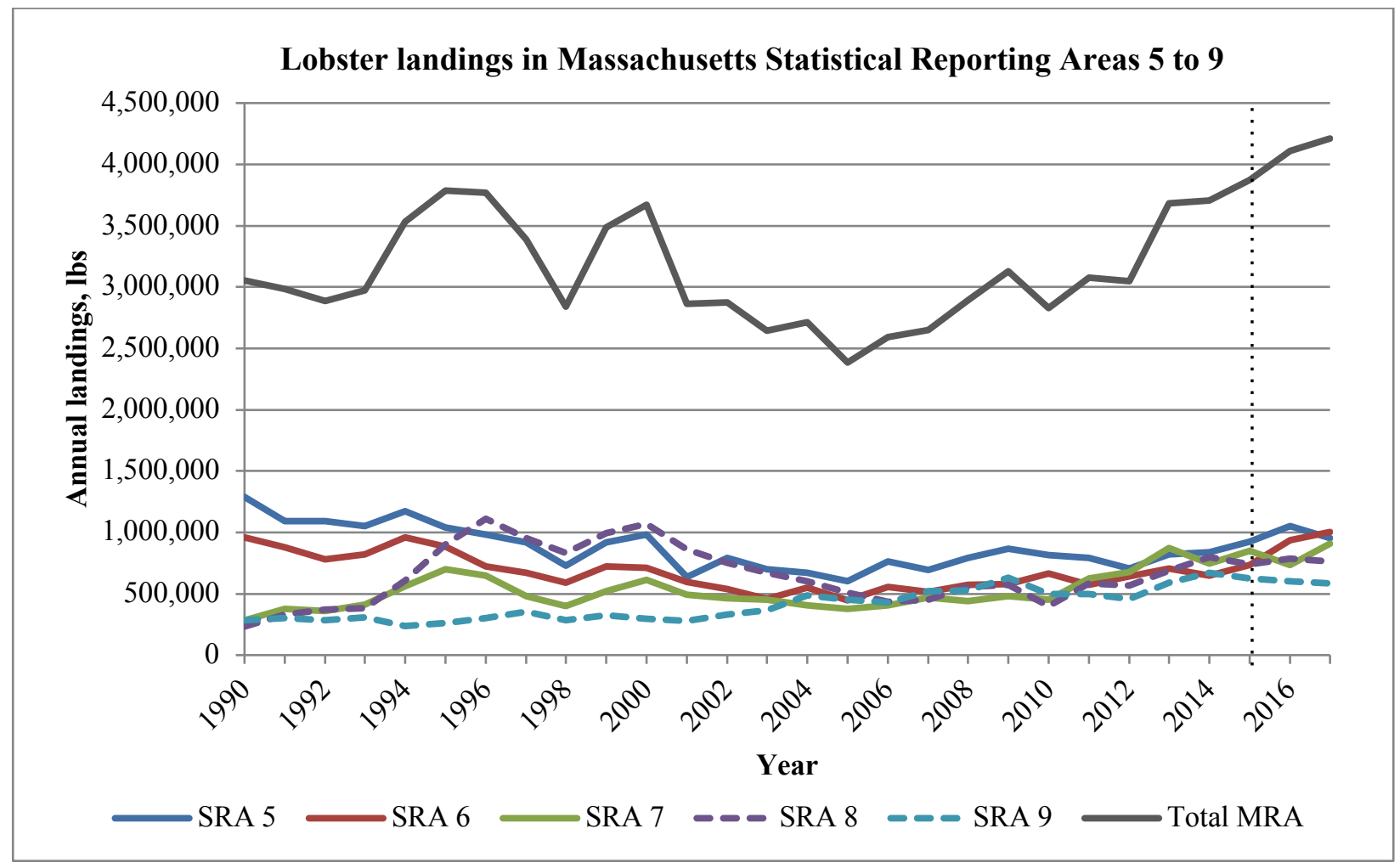

Figure 18: Annual lobster landings weight, in millions of pounds, for Massachusetts Statistical Reporting Areas (SRAs) 5, 6, 7, 8, and 9 from 1990 to 2017. Vertical line indicates the start of the Massachusetts Restricted Area Trap/Pot Closure in 2015. The Massachusetts Restricted Area Trap/Pot Closure includes all of SRAs 6, 7, 8, and 9, as well as most of SRA 5 and small portions of SRAs 18 and 19. Data from the Massachusetts Division of Marine Fisheries (unpublished).

The growth in landings in the Massachusetts Restricted Area is consistent with statewide trends: Massachusetts state landings value reached record highs for all three years for which data are available since the closure was implemented (2015, 2016, and 2017) [Figure 19] (NMFS Annual Commercial Landings Statistics). Massachusetts' landings weight also reached an all-time high in 2016, and 2015 and 2017 were the fifth and third highest years on record, respectively [Figure 19] (NMFS Annual Commercial Landings Statistics). 


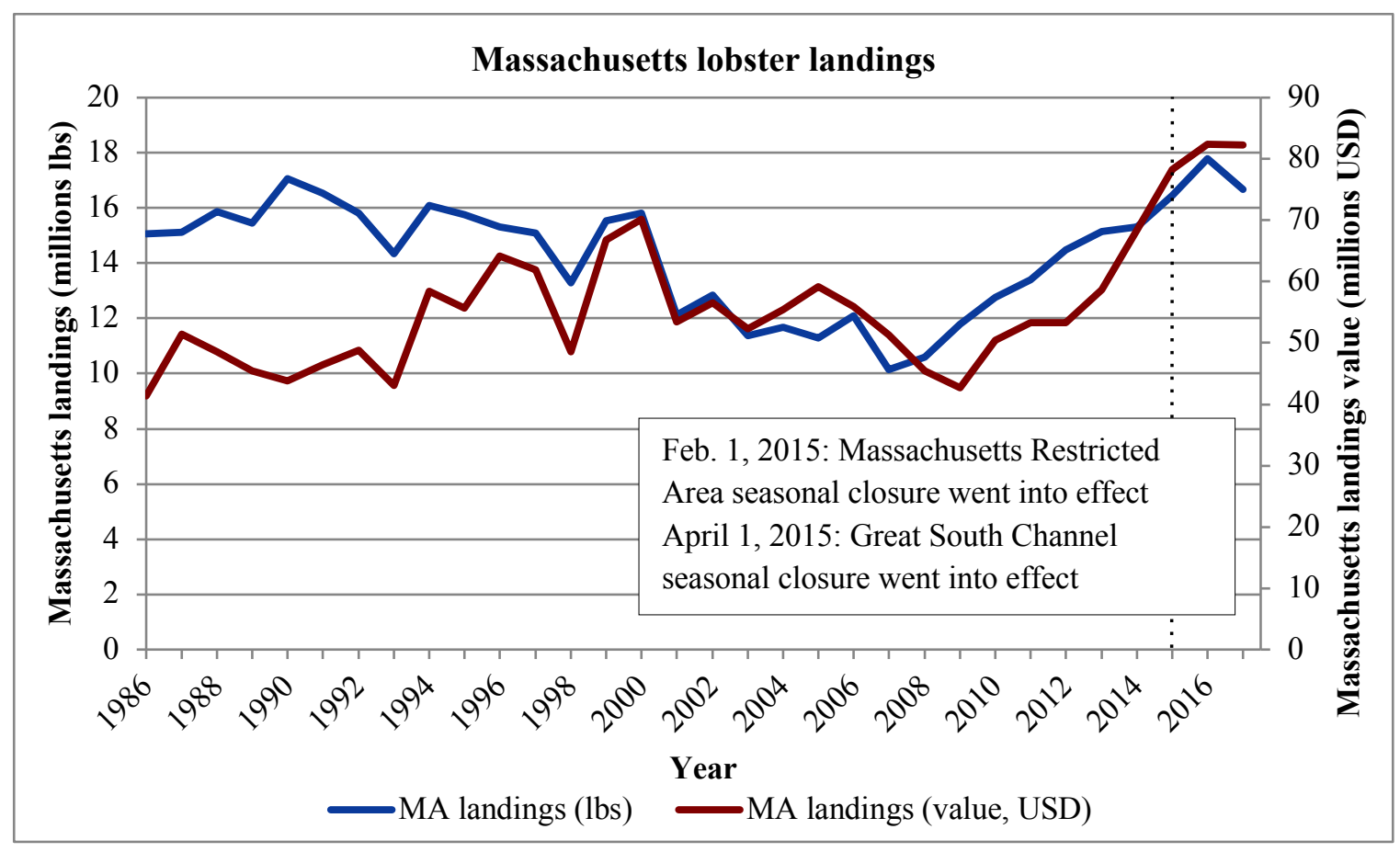

Figure 19: Massachusetts state landings by weight and value from 1986 to 2017. The Massachusetts Restricted Area and Great South Channel seasonal trap/pot closures took effect in 2015. Data from National Marine Fisheries Service Annual Commercial Landings Statistics.

Standardizing landings weight to 1990 in the primary SRAs covered by the Massachusetts Restricted Area and the rest of Massachusetts shows that commercial lobster fishers in SRAs 5 to 9 have experienced stronger growth than those in the rest of the state since the closure was implemented. Landings growth in SRAs 5 to 9 continued consistently since the seasonal closure was implemented on February $1^{\text {st }}, 2015$, but was inconsistent elsewhere [Figure 20]. Notably, landings weight in SRAs 5 to 9 did not drop from 2016 to 2017, in contrast to the rest of Massachusetts and most of the Northeast U.S. When compared to neighboring areas (SRAs 1 to 4 to the north of the Massachusetts Restricted Area and SRAs 10 to 14 to the south), the SRAs covered by the closure have also shown stronger relative growth [Figure 21]. 


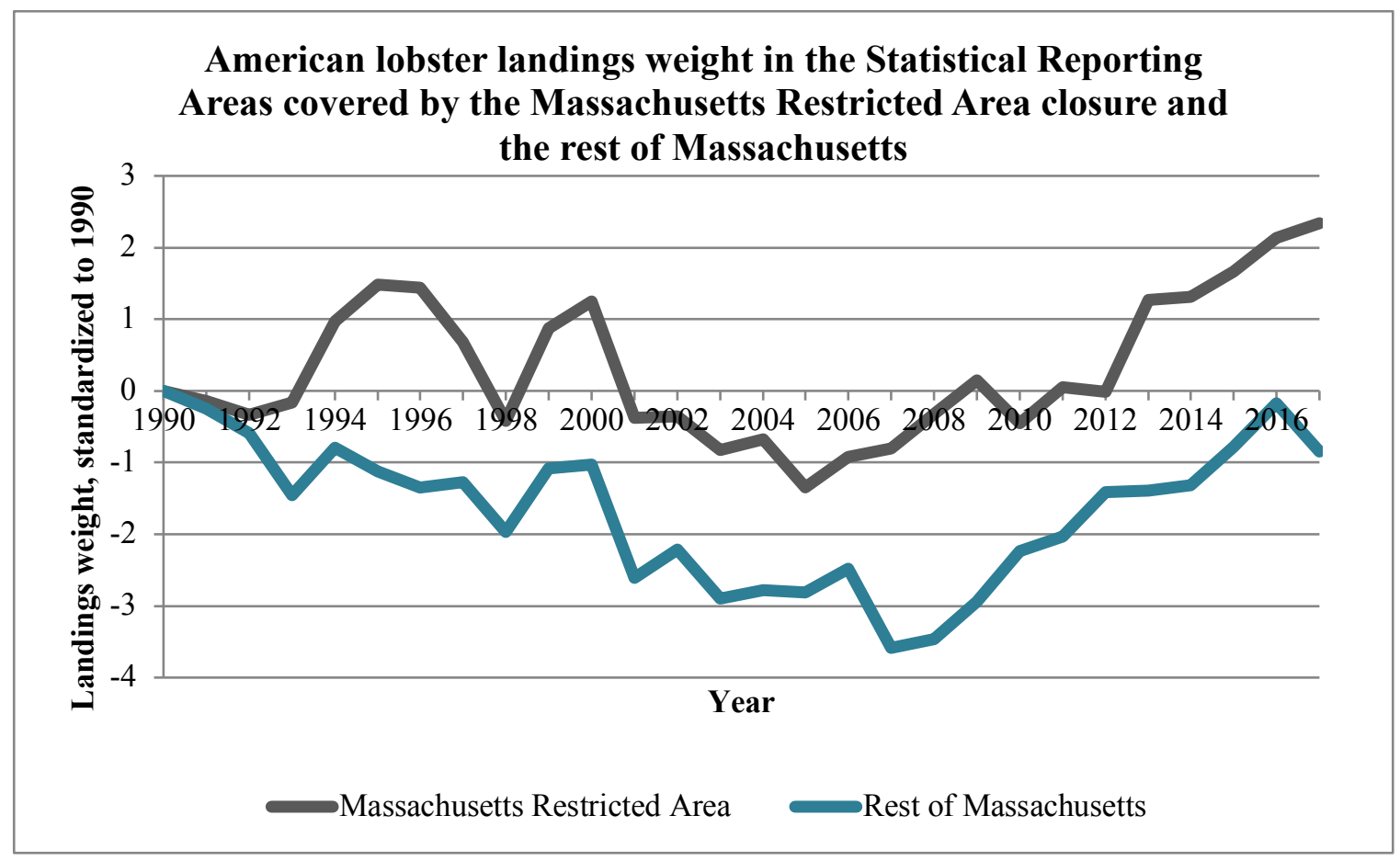

Figure 20: American lobster commercial landings weight standardized to 1990 landings in the primary Statistical Reporting Areas (SRAs) covered by the Massachusetts Restricted Area (SRAs 5, 6, 7, 8, and 9) and the rest of the state of Massachusetts. The Massachusetts Restricted Area seasonal trap/pot fishery closure took place on February $1^{\text {st }}, 2015$. Data from Massachusetts Division of Marine Fisheries (unpublished) and National Marine Fisheries Service Annual Commercial Landings Statistics.

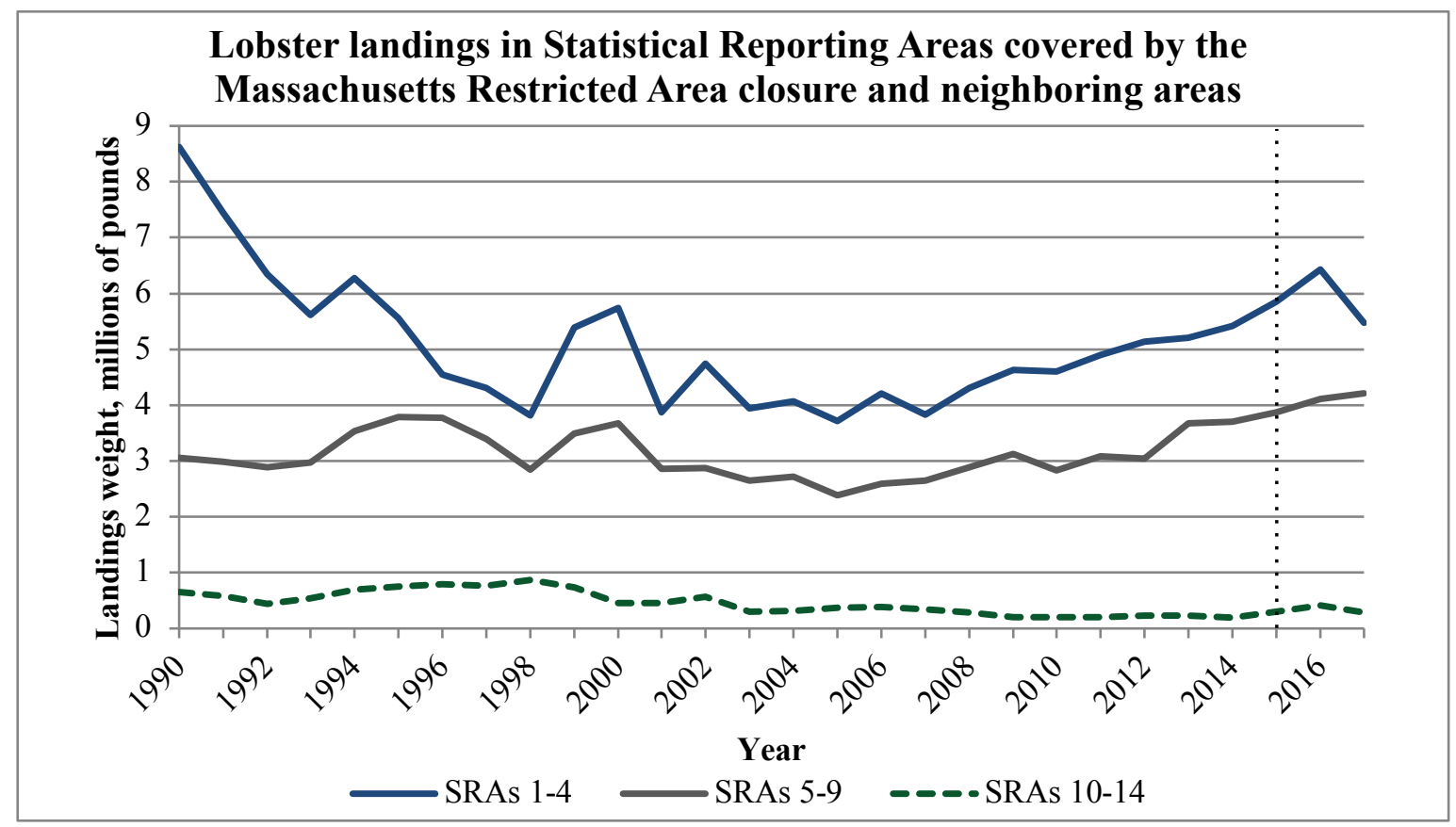

Figure 21: Lobster landings weight in the Statistical Reporting Areas (SRAs) covered by the Massachusetts Restricted Area (5-9) and to the north (1-4) and south (10-14) from 1990 to 2017. Relative growth in landings in SRAs 5 to 9 was stronger than in neighboring areas since the closure was implemented. Vertical line indicates the start of the three-month closure in 2015. Data from Massachusetts Division of Marine Fisheries (unpublished). 
Lobster is not harvested evenly throughout the year, but rather landings are typically low in February, March, and April. This was a significant part of the rationale for amending the Massachusetts Restricted Area closure start date from January $1^{\text {st }}$ to February $1^{\text {st }}$, which NMFS did before the closure was enacted in 2015 (NMFS 2014b). Although landings during the closure period have historically been very low across the state, low weight is in part compensated for by higher price per pound [Figure 22] (Atlantic Coastal Cooperative Statistics Program). Fishers who previously may have harvested during the closure months could have experienced a negative economic impact even if they were able to harvest more weight later on, since they would be selling it for a lower price.

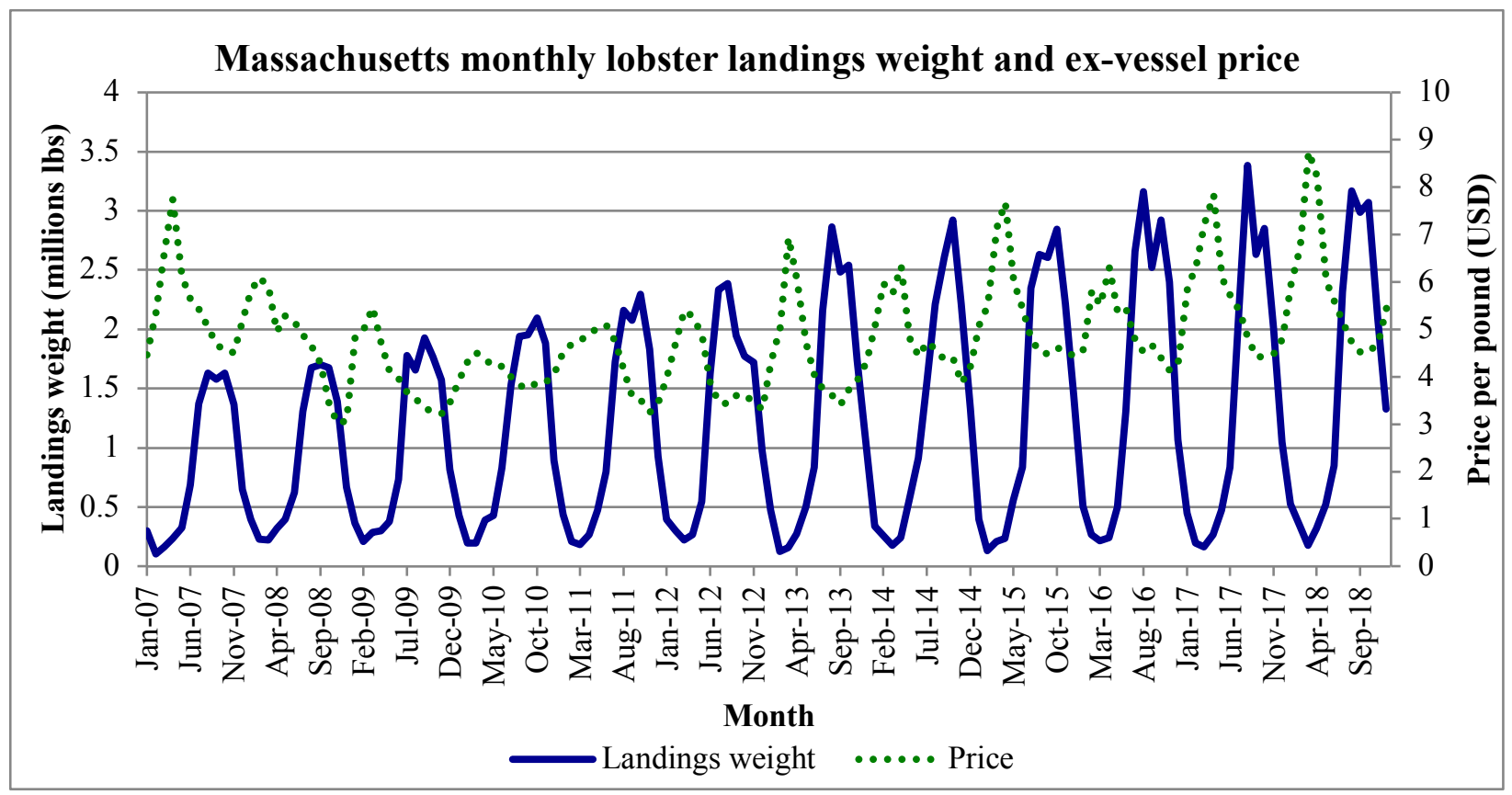

Figure 22: Massachusetts monthly lobster landings weight and ex-vessel price per pound, January 2007 to December 2018. Price is nominal and not adjusted for inflation. Data from Atlantic Coastal Cooperative Statistics Program.

However, average lobster landings from February, March, and April in SRAs 5 to 9 changed by only 19,450 pounds from the four-year period immediately before the Massachusetts Restricted Area closure was implemented (2011 to 2014) to the four-year period immediately after (2015 to 2018) (Massachusetts DMF unpublished data). When monthly landings weight is multiplied by the average price per pound in Massachusetts for each month, we find that this 19,450 pound difference is equivalent to a change in revenue of about $\$ 94,000$ for all of SRAs 5 to 9 (Massachusetts DMF unpublished data) [Figure 23]. Since the closure was implemented, SRAs 5 to 9 have landed an average of 4.16 million pounds of lobster worth about \$19.41 million annually ${ }^{10}$ (Massachusetts DMF unpublished data; NMFS Annual Commercial Landings Statistics). The change in landings during the closure months is therefore worth only about 0.5 percent of annual landings from these areas. On the other hand, annual landings from SRAs 5 to 9 have gone up about 587,800 pounds since the closure was implemented (Massachusetts DMF unpublished data), an overall increase approximately 30 times greater than the amount lost

${ }^{10}$ This value was calculated by multiplying the average annual portion of statewide landings from SRAs 5 to 9 (0.2396) by the average landings value for the state of Massachusetts $(\$ 80,991,600)$ from 2015 to 2017. 
during the closure months. Overall, the loss in landings during the high-price closure period has therefore been more than compensated for by growth in total landings.

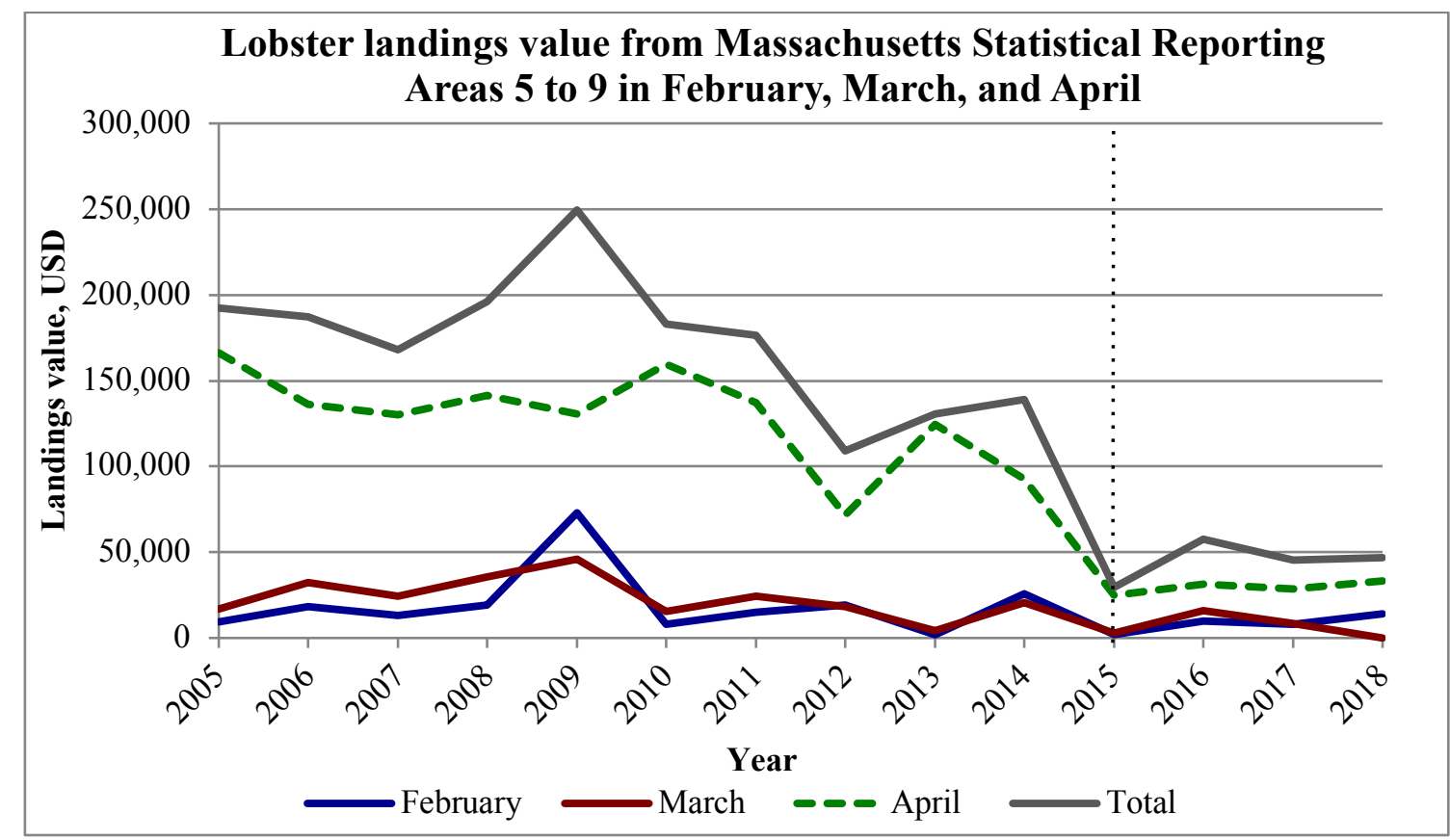

Figure 23: Lobster landings value in February, March, and April from Massachusetts Statistical Reporting Areas 5 to 9, 2005 to 2018 . Landings value from these areas dropped approximately $\$ 94,000$ from the period immediately before to the period immediately after the closure was implemented. Vertical line indicates the start of the Massachusetts Restricted Area trap/pot closure in 2015. Landings value calculated by multiplying landings weight for each area by average price for Massachusetts for that month and year. Value is nominal and not adjusted for inflation. Data from Massachusetts Division of Marine Fisheries (unpublished).

It is important to note that landings by SRA and by state mask individual differences among fishers, some of whom may have lost income due to the closures. This analysis also does not address potential changes in the portions of SRAs 18 and 19 that are covered by the Massachusetts Restricted Area, since finer scale data would be needed to separate landings from the closure portions and the rest of those areas. Additionally, changing local oceanographic conditions affect how much lobster biomass is available to harvest (Goode et al. 2019, Oppenheim et al. 2019), making it difficult to isolate the impact of the closures. However, the available evidence does not demonstrate that the Massachusetts Restricted Area closure has had an overall negative economic impact. Instead, landings have reached record highs, and landings from the primary SRAs covered by the Massachusetts Restricted Area showed stronger and more consistent growth than from the rest of the state. The closure may allow for a buildup in lobster biomass that is brought in later in the season, as can occur with effort reduction (Myers et al. 2007). Lobsters that otherwise would have been caught during the closure period increase in size (leading to higher landings weight if they are caught later on) and contribute to the reproductive cycle to grow the total stock.

Massachusetts' recent experience with the Massachusetts Restricted Area trap/pot closure suggests that seasonal closures will not necessarily cause landings to drop. The reduction in effort that occurred with the closure did not correlate with a drop in landings. In contrast, landings have continued to rise since the closure was implemented. 


\section{Discussion}

Available evidence does not show that landings in the U.S. lobster fishery will necessarily fall with effort reduction. In contrast, in both Maine and Massachusetts an actual or presumed drop in effort has correlated with record high landings, and the significant overcapacity in the Maine fishery compared to Lobster Fishing Area 34 suggests that effort could be substantially reduced and allow fishers to harvest the same landings with lower costs. Therefore, a negative economic impact should not be presumed with right whale bycatch mitigation measures that include or could cause a reduction in fishing effort; the economic impact of effort reduction could in fact be positive.

Although many factors influence total landings, the potential capacity to harvest the same landings with approximately 7.5 times less effort and the correlation between reduced effort and higher landings in the U.S. lobster fishery is typical of an overexploited resource (Worm et al. 2009). It is also in line with international fishing trends: effective catch per unit effort - a standard measure of fishing efficiency calibrated to technological advancement-has decreased by approximately 80 percent in North America from 1950 to 2015, as fishing exploitation has expanded faster than fish stocks can support (Rousseau et al. 2019). Precaution regarding overexploitation is especially important as multiple indicators show that the Gulf of Maine American lobster stock is unlikely to sustain current high abundance levels in the near future (ASMFC 2015; Oppenheim et al. 2019) and as the Gulf of Maine continues to warm at a rapid rate (Pershing et al. 2015; Record et al. 2019).

For the U.S. American lobster fishery to continue to be successful for generations, it is in the best interest of fishers to scale back effort in advance of an ecological or economic crisis (Steneck et al. 2011). As available evidence indicates that the U.S. lobster fishery is currently operating with significant overcapacity, doing so may also support higher profits in the near-term. If fishing effort is scaled back in a manner that reduces the number and strength of vertical endlines, it will simultaneously serve to reduce entanglement risk for North Atlantic right whales. This study provides particular support for a trap reduction implemented in concert with a set minimum number of traps per trawl or an endline cap, as well as seasonal closures. Additional closures in areas of high right whale aggregation could provide significant conservation benefit and may not have a net negative economic impact if overall landings gains exceed losses during the closure period. Other right whale protection measures that may indirectly lead to a reduction in effort, such as ropeless fishing, could also serve to reduce overexploitation in the lobster fishery. Implementing ropeless fishing together with a trap reduction could strengthen this benefit while reducing the upfront cost of technological transition.

After decades of insufficient protections, the U.S. American lobster fishery is facing potentially significant new regulations to protect North Atlantic right whales from entanglement. However, a negative economic impact should not be presumed with such measures; right whale bycatch mitigation measures that include or could cause a reduction in lobster fishing effort may support higher profits and the long-term sustainability of the fishery. 


\section{Acknowledgments}

We thank Erica Fuller of the Conservation Law Foundation and Burton Shank from the National Oceanic and Atmospheric Administration's Northeast Fisheries Science Center for their review and feedback on this manuscript.

\section{Works Cited}

Abel, D. 2019a. New regulations are a matter of life and extinction for right whales. Boston Globe, Boston, MA: published April 20 2019.

https://www.bostonglobe.com/metro/2019/04/20/how-federal-officials-hope-protectendangered-right-whales-cape-cod-bay/I57nFpeibxyuslQDeevYYO/story.html

Abel, D. 2019b. Fishing areas off Cape Cod reopened for lobstermen. Boston Globe, Boston, MA: published May $10^{\text {th }}, 2019$.

https://www.bostonglobe.com/metro/2019/05/09/lobstermen-plan-rally-plymouth-protestclosure-fishing-areas-off-cape-cod/ocT3A0SidX0H35TjiweHCL/story.html

Arthur, L.H., W.A. McLellan, M.A. Piscitelli, S.A. Rommel, B.L. Woodward, J.P. Winn, C.W. Potter, D.A. Pabst. 2015. Estimating maximal force output of cetaceans using axial locomotor muscle morphology. Marine Mammal Science, 31(4): 1401-1426. doi: $10.1111 / \mathrm{mms} .12230$

Atlantic Coastal Cooperative Statistics Program. (1990-2018). Data Warehouse, Confidential, Commercial Landings, Summary; generated by Chao Zou; using Data Warehouse [online application], Arlington, VA: Available at https://www.accsp.org; Login Data Warehouse; accessed (November $\left.8^{\text {th }}, 2019\right)$.

Atlantic States Marine Fisheries Commission (ASMFC). 2015. American lobster stock assessment peer review report. A publication of the Atlantic States Marine Fisheries Commission pursuant to National Oceanic and Atmospheric Administration Award No. NA10NMF4740016.

http://www.asmfc.org/uploads/file//55d61d73AmLobsterStockAssmt_PeerReviewReport Aug2015_red2.pdf

Atlantic States Marine Fisheries Commission (ASMFC). 2018. Addendum XXVI to Amendment 3 to the American Lobster Fishery Management Plan; Addendum III to the Jonah Crab Fishery Management Plan; Harvester Reporting and Biological Data Collection. https:/www.asmfc.org/uploads/file/5a9438ccAmLobsterAddXXVI_JonahCrabAddIII_F eb2018.pdf

Atlantic States Marine Fisheries Commission (ASMFC). 2018. 2018 Review of the Atlantic States Marine Fisheries Commission Fishery Management Plan for American Lobster (Homarus americanus), 2017 Fishing Year. http://www.asmfc.org/uploads/file/5bdb531a2018AmLobsterFMPReview.pdf

Atlantic States Marine Fisheries Commission. American Lobster, Map of Stock Assessment and Management Areas. November 2016. http://www.asmfc.org/species/american-lobster

Casoni, B. 2019. The Massachusetts Perspective. Right Whale News, Vol. 27, No. 2, September 2019, p. 11-12. http://www.narwc.org/uploads/1/1/6/6/116623219/rwn-sep19.pdf

Casoni, D. 2018. Massachusetts Lobster Industry's Hard Work in Preserving Right Whales. Presentation to the Atlantic Large Whale Take Reduction Team, October $10^{\text {th }}, 2018$, Providence, RI. 
https://www.greateratlantic.fisheries.noaa.gov/protected/whaletrp/trt/meetings/October\% 202018/mla_d_casoni_ropeless_presentation_fin.pdf

Chami, R., T. Cosimano, C. Fullenkamp, and S. Oztosun. 2019. Nature's Solution to Climate Change: A strategy to protect whales can limit greenhouse gases and global warming. Finance and Development Magazine, International Monetary Fund, September 2019. https://www.imf.org/external/pubs/ft/fandd/2019/12/natures-solution-to-climate-changechami.htm

Davis, G.E., M.F. Baumgartner, J.M. Bonnell, J. Bell, C. Berchok, J. Bort Thornton, S. Brault, G. Buchanan, R.A. Charif, D. Cholewiak, C.W. Clark, P. Corkeron, J. Delarue, K. Dudzinski, L. Hatch, J. Hildebrand, L. Hodge, H. Klinck, S. Kraus, B. Martin, D.K. Mellinger, H. Moors-Murphy, S. Nieukirk, D.P. Nowacek, S. Parks, A.J. Read, A.N. Rice, D. Risch, A. Širović, M. Soldevilla, K. Stafford, J.E. Stanistreet, E. Summers, S. Todd, A. Warde, S.M. Van Parijs. 2017. Long-term passive acoustic recordings track the changing distribution of North Atlantic right whales (Eubalaena glacialis) from 2004 to 2014. Scientific Reports, 7(1): 13460. doi: 10.1038/s41598-017-13359-3

Dolman, S.J. and M.J. Moore. 2017. 'Welfare Implications of Cetacean Bycatch and Entanglements' in A. Butterworth (ed.) Marine Mammal Welfare. Springer. 41-65. doi: 10.1007/978-3-319-46994-2

Fisheries and Oceans Canada (DFO). 2011. Integrated Fishery Management Plan, Lobster Fishing Areas 27 - 38, Scotia-Fundy Sector, Maritimes Region. http://www.dfompo.gc.ca/fisheries-peches/ifmp-gmp/maritimes/inshore-lobster-2011-eng.html

Fisheries and Oceans Canada (DFO). 2019. Integrated Fisheries Management Plan for Lobster Fishing Areas 27-38, Maritimes Region. Updated March 2019.

Fisheries and Oceans Canada (DFO). Atlantic Region Licences. Last updated February 1 ${ }^{\text {st }}, 2019$. http://www.dfo-mpo.gc.ca/stats/commercial/licences-permis/licences-permis-atl-eng.htm

Fisheries and Oceans Canada (DFO). Seafisheries Landings. Last updated January 31 ${ }^{\text {st }}, 2019$. https://www.dfo-mpo.gc.ca/stats/commercial/sea-maritimes-eng.htm

Free, C.M. 2017. Mapping Canada's fish stock boundaries. Sustainable Fisheries Group, University of California Santa Barbara. Last updated May $2^{\text {nd }}, 2017$. Accessed November $4^{\text {th }}, 2019$. https://marine.rutgers.edu/ cfree/mapping-canadas-fishing-areas/

Goode, A.G., D.C. Brady, R.S. Steneck, R.A. Wahle. 2019. The brighter side of climate change: How local oceanography amplified a lobster boom in the Gulf of Maine. Global Change Biology, 25: 3906-3917. doi: 10.1111/gcb.14778

Greater Atlantic Region Fisheries Office (GARFO), National Marine Fisheries Service, National Oceanic and Atmospheric Administration. American Lobster. 2019. https://www.fisheries.noaa.gov/species/american-lobster

Hayes, S.A., S. Gardner, L. Garrison, A. Henry, L. Leandro. 2018a. North Atlantic right whalesevaluating their recovery challenges in 2018. National Oceanic and Atmospheric Administration Technical Memorandum NMFS-NE-247; 24 p. doi: 10.25923/w9cy-5844

Hayes, S.A., E. Josephson, K. Maze-Foley, P.E. Rosel, B. Byrd, S. Chavez-Rosales, T.V.N. Cole, L. Engleby, L.P. Garrison, J. Hatch, A. Henry, S.C. Horstman, J. Litz, M.C. Lyssikatos, K.D. Mullin, C. Orphanides, R.M. Pace, D.L. Palka, M. Soldevilla, F.W. Wenzel. 2018b. US Atlantic and Gulf of Mexico Marine Mammal Stock Assessments 2017, second ed., NOAA Technical Memorandum NMFS-NE-245. 
Knowlton, A.R., P.K. Hamilton, M.K. Marx, H.M. Pettis, S.D. Kraus. 2012. Monitoring North Atlantic right whale (Eubalaena glacialis) entanglement rates: a 30 year retrospective. Marine Ecology Progress Series, 466: 293-302. doi: 10.3354/ meps09923

Knowlton, A.R., J. Robbins, S. Landry, H.A. McKenna, S.D. Kraus, T.B. Werner. 2016. Implications of fishing rope strength on the severity of large whale entanglements. Conservation Biology, 30(2): 318-328. doi: 10.1111/cobi.12590

Kraus, S.D., P.K. Hamilton, R.D. Kenney, A.R. Knowlton, C.K. Slay. 2001. Reproductive parameters of the North Atlantic right whale. Journal of Cetacean Research and Management, 2: 231-236.

Lavery, T.J., B. Roudnew, P. Gill, J. Seymour, L. Seuront, G. Johnson, J.G. Mitchell, V. Smetacek. 2010. Iron defecation by sperm whales stimulates carbon export in the Southern Ocean. Proceedings of the Royal Society B. 277, 3527-3531. doi:10.1098/rspb.2010.0863.

Maine Department of Marine Resources (DMR). Historical Maine Lobster Landings. Last updated February 19 ${ }^{\text {th }}, 2019$. https://www.maine.gov/dmr/commercial-

fishing/landings/documents/lobster.table.pdf

Maine Lobstermen's Association. 2019. MLA Withdraws from TRT April 2019 Agreement Due to "serious data flaws." Posted August 30"th 2019. https://mainelobstermen.org/2019/08/30/mla-withdraws-from-trt-april-2019-agreementdue-to-serious-data-flaws/?preview $=$ true

Meyer-Gutbrod, E.L. and C.H. Greene. 2018. Uncertain recovery of the North Atlantic right whale in a changing ocean. Global Change Biology, 24: 455-464. doi:10.1111/gcb.13929

Marine Mammal Protection Act (MMPA). 1972. United States of America, 16 USC 1361-1407, Chapter 31 - Marine Mammal Protection.

Massachusetts Division of Marine Fisheries (DMF). Trap Gear Closure Lifted; Right Whales Leaving Cape Cod Bay. Marine Fisheries Advisory, published May 4, 2017. https:/www.mass.gov/files/documents/2017/05/zy/CCB\%2520Opening\%2520Notice\%2 520050417.pdf

Massachusetts Division of Marine Fisheries (DMF). Trap Gear Closure and Speed Limit in Cape Cod Bay Lifted Today (Tuesday, May 15, 2018). Marine Fisheries Advisory, published May 15, 2018.

https://www.mass.gov/files/documents/2018/05/15/ccb\%20closure\%20opening\%200515 18.pdf

Massachusetts Division of Marine Fisheries (DMF). Director's Declaration: Large Whale Seasonal Trap Gear Closure Extension. Published May 6, 2019. https://www.mass.gov/files/documents/2019/05/06/Seasonal\%20Trap\%20Gear\%20Closu re\%20Extension_Declaration_190506.pdf

Massachusetts Division of Marine Fisheries (DMF). 2019. Massachusetts state lobster permits and landings. Unpublished data, report run April 2019.

Massachusetts Division of Marine Fisheries (DMF). 2019. MA Lobster Fishery, Live Pounds by SRA and Year, 1990-2017. Unpublished data, report run August 2019.

Massachusetts Division of Marine Fisheries (DMF). 2019. MA Lobster Landings by Year, Month, and SRA, 1990-2018; MA Lobster Average Monthly Price Per Pound, 20052019. Unpublished data, report run November 2019. 
MassGIS (Bureau of Geographic Information) Division of Marine Fisheries. MA Division of Marine Fisheries Lobster Harvest Zones. Published August 1999, shapefile last modified January $5^{\text {th }}, 2018$. aff5f573-fc4c-4977-8d2e-4df9950ec664

MassGIS (Bureau of Geographic Information). New England Boundaries. Published September 2007, shapefile last modified December $10^{\text {th }}$, 2018. 649cd2e3-a61f-438c-b118bef4c7ca6923

MassGIS (Bureau of Geographic Information). State Outline. Published March 1991, shapefile last modified December $6^{\text {th }}, 2018.4952 \mathrm{f54a-5a89-4a7e-97f9-b655912155ca}$

National Marine Fisheries Service (NMFS). 2019. Key Outcomes Memorandum: Atlantic Large Whale Take Reduction Team Meeting, April 23-26, 2019, Providence, Rhode Island.

Prepared by S. McCreary and B. Brooks, published October 4, 2019.

https://www.fisheries.noaa.gov/new-england-mid-atlantic/marine-mammalprotection/atlantic-large-whale-take-reduction-plan

Moore, M.J., A.R. Knowlton, S.D. Kraus, W.A. McLellan, R.K. Bonde. 2004. Morphometry, gross morphology and available histopathology in North Atlantic right whale (Eubalaena glacialis) mortalities (1970-2002). Journal of Cetacean Research and Management, 6(3): 199-214.

Moore, M.J., A. Bogomolni, R. Bowman, P. Hamilton, C. Harry, A. Knowlton, S. Landry. 2006. Fatally entangled right whales can die extremely slowly. Oceans'06 MTS/IEEE-Boston, Massachusetts, September 18-21, 2006. https://darchive.mblwhoilibrary.org/bitstream/handle/1912/1505/?sequence=1.

Moore, M.J. and J.M. van der Hoop. 2012. The painful side of trap and fixed net fisheries: chronic entanglement of large whales. Journal of Marine Biology, Article ID 230653, 4 pp. doi: 10.1155/2012/230653

Moore, M.J. 2013. Welfare of whales by-caught in fishing gear or struck by vessels. Animal Welfare, 22: 117-121. doi: 10.7120/09627286.22.1.117

Moore, M.J. 2014. How we all kill whales. ICES Journal of Marine Science, 71(4): 760-763. doi: 10.1093/icesjms/fsu008

Monsarrat, S., M. Grazia Pennino, T.D. Smith, R.R. Reeves, C.N. Meynard, D.M. Kaplan, A.S.L. Rodrigues. 2015. A spatially explicit estimate of the prewhaling abundance of the endangered North Atlantic right whale. Conservation Biology 30(4): 783-791. doi: 10.1111/cobi.12664

Morin, D., G. Salvador, J. Higgins, M. Minton. 2018a. Gear analysis and protocols; Overview of preliminary gear analysis 2007-2017. Presentation to the Atlantic Large Whale Take Reduction Team, April 3-4, 2018, Warwick RI. https://www.greateratlantic.fisheries.noaa.gov/protected/whaletrp/trt/meetings/Weak\%20 Rope\%20Subgroup/2007_-_2017_alwtrt_gear_update_4_18.pdf.

Morin, D., A. Henry, J. Higgins, M. Minton. 2018b. Atlantic Large Whale Take Reduction Team Entanglement Summary, Serious Injury/Mortality and Gear Analysis. Presentation to the Atlantic Large Whale Take Reduction Team, October $9^{\text {th }}, 2018$, Providence, RI. https://www.greateratlantic.fisheries.noaa.gov/protected/whaletrp/trt/meetings/October\% 202018/2018_fall_alwtrt_entanglement_update.pdf

Morin, D. Large Whale Disentanglement Coordinator, Greater Atlantic Regional Fisheries Office, NOAA. Personal communication, August 16 ${ }^{\text {th }}, 2019$. 
Myers, R.A., S.A. Boudreau, R.D. Kenney, M.J. Moore, A.A. Rosenberg, S.A. Sherrill, B. Worm. 2007. Saving endangered whales at no cost. Current Biology, 17(1). doi: 10.1016/j.cub.2006.11.045.

Myers, H.J., M.J. Moore, M.F. Baumgartner, S.W. Brillant, S.K. Katona, A.R. Knowlton, L. Morissette, H.M. Pettis, G. Shester, T.B. Werner. 2019. Ropeless Fishing to Prevent Large Whale Entanglements: Ropeless Consortium Report. Marine Policy 107. doi: 10.1016/j.marpol.2019.103587

National Marine Fisheries Service (NMFS), National Oceanic and Atmospheric Administration, Commerce. 1997. Taking of Marine Mammals Incidental to Commercial Fishing Operations; Atlantic Large Whale Take Reduction Plan Regulations. Federal Register, 62(140): 39157-39188.

National Marine Fisheries Service (NMFS), National Oceanic and Atmospheric Administration (NOAA), Commerce. 1999. American Lobster Fishery; Final Rule. Federal Register, 64(233): 68228-68262.

National Marine Fisheries Service (NMFS), National Oceanic and Atmospheric Administration (NOAA), Commerce. 2007. Taking of Marine Mammals Incidental to Commercial Fishing Operations; Atlantic Large Whale Take Reduction Plan Regulations; Final Rule. Federal Register, 72(193): 57104-57194.

National Marine Fisheries Service (NMFS). 2014a. Northeast region, Section 7 Consultation on the American Lobster Fishery. NMFS tracking number NER2014-11076.

National Marine Fisheries Service (NMFS), National Oceanic and Atmospheric Administration, Commerce. 2014b. Taking of Marine Mammals Incidental to Commercial Fishing Operations and Atlantic Coastal Fisheries Cooperative Management Act Provisions; American Lobster Fishery; Final Rule. Federal Register, 79(239): 73848-73852.

National Marine Fisheries Service, National Oceanic and Atmospheric Administration (NOAA), Commerce. 2016. Endangered and Threatened Species; Critical Habitat for Endangered North Atlantic Right Whale; Final Rule. Federal Register, 81(17): 4837-4874.

National Marine Fisheries Service (NMFS), National Oceanic and Atmospheric Administration (NOAA), Commerce. 2019a. Atlantic Large Whale Take Reduction Plan Modifications To Reduce Serious Injury and Mortality of Large Whales in Commercial Trap/Pot Fisheries Along the U.S. East Coast: Notice of intent to prepare environmental impact statement, request for comments. Federal Register 84(149): 37822-37824.

National Marine Fisheries Service (NMFS), National Oceanic and Atmospheric Administration (NOAA), Commerce. 2019b. List of Fisheries for 2019; Final Rule. Federal Register, 84(95): 22051-22073.

National Marine Fisheries Service (NMFS), National Oceanic and Atmospheric Administration (NOAA), Commerce. 2019c. Magnuson-Stevens Act Provisions; Fisheries of the Northeastern United States; Atlantic Herring Fishery; Adjustment to Atlantic Herring Specifications and Sub-Annual Catch Limits for 2019; Final Rule. Federal Register, 84(27): 2760-2767.

National Marine Fisheries Service (NMFS) co-occurrence model. 2019. Prepared by Industrial Economics, Incorporated for the National Marine Fisheries Service Greater Atlantic Fisheries Office and the Atlantic Large Whale Take Reduction Team. Preliminary Draft Baseline model runs completed in April 2019. Presentation to the Take Reduction Team on Risk Reduction Tool, April 26 ${ }^{\text {th }}, 2019$. 
https://www.greateratlantic.fisheries.noaa.gov/protected/whaletrp/trt/meetings/April\%202 019/apr_16_risk_reduction_decision_tool_webinar_full_slide_deck.pdf

National Marine Fisheries Service (NMFS) correspondence. Letter to the Atlantic Large Whale Take Reduction Team; Take Reduction Target. Sent by C. Coogan, April 5 th $_{2019 .}$ https://www.greateratlantic.fisheries.noaa.gov/protected/whaletrp/trt/meetings/April\%202 019/06_take_reduction_target_letter_april52019.html

National Marine Fisheries Service (NMFS), Office of Protected Resources. Reducing Ship Strikes to North Atlantic Right Whales. Last updated May 29 ${ }^{\text {th }}, 2019$. https://www.fisheries.noaa.gov/national/endangered-species-conservation/reducing-shipstrikes-north-atlantic-right-whales.

National Marine Fisheries Service (NMFS), Office of Science and Technology. Annual Commercial Landings Statistics. Accessed July 3 ${ }^{\text {rd }}, 2019$. https://www.st.nmfs.noaa.gov/commercial-fisheries/commercial-landings/annuallandings/index

National Marine Fisheries Service (NMFS). 2017-2019 North Atlantic Right Whale Unusual Mortality Event. Last updated October $4^{\text {th }}$, 2019. https://www.fisheries.noaa.gov/national/ marine-life-distress/2017-2018-north-atlantic-right-whale-unusual-mortality- event

National Marine Fisheries Service Northeast Fisheries Science Center. Eubalaena glacialis human interaction serious injuries and all mortalities 2000 to 2017. Unpublished data, report run July 2019.

National Oceanic and Atmospheric Administration (NOAA) Northeast Fisheries Science Center Protected Species Branch. NOAA Right Whale Sighting Advisory System. Accessed July $5^{\text {th }}, 2019$. https://www.nefsc.noaa.gov/psb/surveys/MapperiframeWithText.html

NOAA National Marine Fisheries Service, Greater Atlantic Regional Fisheries Office (GARFO). Great South Channel Restricted Trap/Pot Area. Gloucester, MA: shapefile published June $5^{\text {th }}, 2015$. http://www.greateratlantic.fisheries.noaa.gov/gis.

NOAA National Marine Fisheries Service, Greater Atlantic Regional Fisheries Office (GARFO). Massachusetts Restricted Area. Gloucester, MA: shapefile published June $5^{\text {th }}, 2015$. http://www.greateratlantic.fisheries.noaa.gov/gis.

NOAA National Marine Fisheries Service, Greater Atlantic Regional Fisheries Office (GARFO). Lobster Management Areas. Gloucester, MA: shapefile published May 1" 2016. http://www.greateratlantic.fisheries.noaa.gov/gis.

Oliver, C. 2019. Letter to Ms. Patrice McCarron, Executive Director, Maine Lobstermen's Association, Inc. October $2^{\text {nd }}, 2019$. Assistant Administrator for Fisheries, National Marine Fisheries Service.

Oppenheim, N.G., R.A. Wahle, D.C. Brady, A.G. Goode, A.J. Pershing. 2019. The cresting wave: larval settlement and ocean temperatures predict change in the American lobster harvest. Ecological Applications, e02006. doi:10.1002/eap.2006

Pace, R.M., P.J. Corkeron, S.D. Kraus. 2017. State-space mark-recapture estimates reveal a recent decline in abundance of North Atlantic right whales. Ecology and Evolution, 7: 8730-8741. doi: 10.1002/ece3.3406

Pershing, A.J., L.B. Christensen, N.R. Record, G.D. Sherwood, P.B. Stetson. 2010. The impact of whaling on the ocean carbon cycle: Why bigger was better. PLoS ONE 5(8): e12444. doi: 10.1371/journal.pone.0012444

Pershing, A.J., M.A. Alexander, C.M. Hernandez, L.A. Kerr, A. Le Bris, K.E. Mills, J.A. Nye, N.R. Record, H.A. Scannell, J.D. Scott, G.D. Sherwood, A.C. Thomas. 2015. Slow 
adaptation in the face of rapid warming leads to collapse of the Gulf of Maine cod fishery. Science, 350(6262): 809-812. doi: 10.1126/science.aac9819

Pettis, H.M., R.M. Pace III, P.K. Hamilton. 2018. North Atlantic Right Whale Consortium Annual Report Card 2018. Report to the North Atlantic Right Whale Consortium, November 2018. www.narwc.org

Record, N.R., J.A. Runge, D.E. Pendleton, W.M. Balch, K.T.A. Davies, A.J. Pershing, C.L. Johnson, K. Stamieszkin, R. Ji, Z. Feng, S.D. Kraus, R.D. Kenney, C.A. Hudak, C.A. Mayo, C. Chen, J.E. Salisbury, C.R.S. Thompson. 2019. Rapid Climate-Driven Circulation Changes Threaten Conservation of Endangered North Atlantic Right Whales. Oceanography, 32(2): 162-169. doi: 10.5670/oceanog.2019.201

Roman, J., J.A. Estes, L. Morissette, C. Smith, D. Costa, J. McCarthy, J.B. Nation, S. Nicol, A. Pershing, V. Smetacek. 2014. Whales as marine ecosystem engineers. Frontiers in Ecology and the Environment, 12(7). doi: 10.1890/130220

Rousseau, Y., R.A. Watson, J.L. Blanchard, E.A. Fulton. 2019. Evolution of global marine fishing fleets and the response of fished resources. Proceedings of the National Academy of Sciences, 116(25): 12238-12243. doi: 10.1073/pnas. 1820344116

Sharp, S.M., W.A. McLellan, D.S. Rotstein, A.M. Costidis, S.G. Barco, K. Durham, T.D. Pitchford, K. A. Jackson, P.-Y. Daoust, T. Wimmer, E.L. Couture, L. Bourque, T. Frasier, B. Frasier, D. Fauquier, T. K. Rowles, P. K. Hamilton, H. Pettis, M. J. Moore. 2019. Gross and histopathologic diagnoses from North Atlantic right whale Eubalaena glacialis mortalities between 2003 and 2018. Diseases of Aquatic Organisms, 135: 1-31. doi: 10.3354/dao03376

Steneck, R.S., T.P. Hughes, J.E. Cinner, W.N. Adger, S.N. Arnold, F. Berkes, S.A. Boudreau, K. Brown, C. Folke, L. Gunderson, P. Olsson, M. Scheffer, E. Stephenson, B. Walker, J. Wilson, and B. Worm. 2011. Creation of a Gilded Trap by the High Economic Value of the Maine Lobster Fishery. Conservation Biology, 25(5): 904-912. doi: 10.1111/j.15231739.2011.01717.x

U.S. Bureau of Labor Statistics. Producer Price Index by Commodity for Processed Foods and Feeds: Unprocessed Shellfish [WPU022305]. Retrieved from FRED, Federal Reserve Bank of St. Louis; https://fred.stlouisfed.org/series/WPU022305, November $8^{\text {th }}, 2019$.

van der Hoop, J.M., P. Corkeron, J. Kenney, S. Landry, D. Morin, J. Smith, M.J. Moore. 2016. Drag from fishing gear entangling North Atlantic right whales. Marine Mammal Science, 32(2): 619-642. doi: $10.1111 / \mathrm{mms} .12292$

van der Hoop, J., P. Corkeron, M. Moore. 2017. Entanglement is a costly life-history stage in large whales. Ecology and Evolution, 7(1): 92-106, doi: 10.1002/ece3.2615.

Waring, G.T., D.L. Palka, K.D. Mullin, J.H.W. Hain, L.J. Hansen, K.D. Bisack. 1997. U.S. Atlantic and Gulf of Mexico Marine Mammal Stock Assessments - 1996. U.S. Department of Commerce, NOAA Tech Memo NMFS NE 114, 251p.

Waring, G.T., J.M. Quintal, C.P. Fairfield, ed. 2002. U.S. Atlantic and Gulf of Mexico Marine Mammal Stock Assessments - 2002. NOAA Tech Memo NMFS NE 169, 318p.

Waring, G.T., E. Josephson, K. Maze-Foley, P.E. Rosel, ed. 2016. U.S. Atlantic and Gulf of Mexico Marine Mammal Stock Assessments - 2015. NOAA Tech Memo NMFS NE 238, $501 \mathrm{p}$.

Worm, B., R. Hilborn, J.K. Baum, T.A. Branch, J.S. Collie, C. Costello, M.J. Fogarty, E.A. Fulton, J.A. Hutchings, S. Jennings, O.P. Jensen, H.K. Lotze, P.M. Mace, T.R. McClanahan, C. Minto, S.R. Palumbi, A.M. Parma, D. Ricard, A.A. Rosenberg, R. 
Watson, D. Zeller. 2009. Rebuilding Global Fisheries. Science, 325(5940): 578-585. doi: $10.1126 /$ science. 1173146 